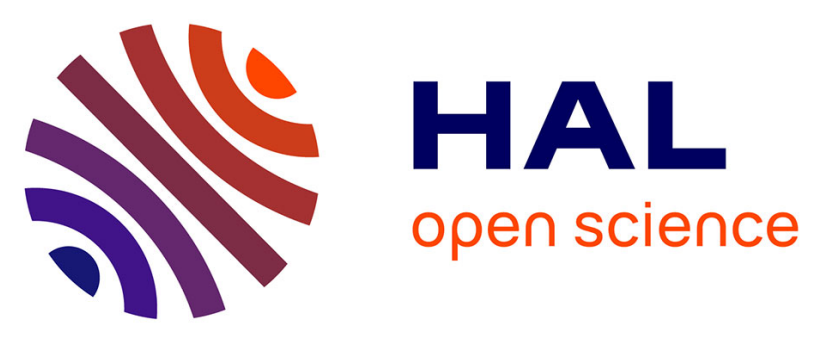

\title{
Atmospheric nitrous acid (HONO) in an alternate process of haze pollution and ozone pollution in urban Beijing in summertime: Variations, sources and contribution to atmospheric photochemistry
}

Yunfeng Li, Xuezhong Wang, Zhenhai Wu, Ling Li, Chuhan Wang, Hong Li, Xin Zhang, Yingnan Zhang, Junling Li, Rui Gao, et al.

\section{To cite this version:}

Yunfeng Li, Xuezhong Wang, Zhenhai Wu, Ling Li, Chuhan Wang, et al.. Atmospheric nitrous acid (HONO) in an alternate process of haze pollution and ozone pollution in urban Beijing in summertime: Variations, sources and contribution to atmospheric photochemistry. Atmospheric Research, 2021, 260, pp.105689. 10.1016/j.atmosres.2021.105689 . hal-03305628

\section{HAL Id: hal-03305628 \\ https://hal.science/hal-03305628}

Submitted on 27 Oct 2021

HAL is a multi-disciplinary open access archive for the deposit and dissemination of scientific research documents, whether they are published or not. The documents may come from teaching and research institutions in France or abroad, or from public or private research centers.
L'archive ouverte pluridisciplinaire HAL, est destinée au dépôt et à la diffusion de documents scientifiques de niveau recherche, publiés ou non, émanant des établissements d'enseignement et de recherche français ou étrangers, des laboratoires publics ou privés. 

19 20 1 22 33 4 25

\section{Atmospheric nitrous acid (HONO) in an alternate process of haze} pollution and ozone pollution in urban Beijing in summertime:

Variations, sources and contribution to atmospheric photochemistry

Yunfeng $\mathrm{Li}^{1,2}$, Xuezhong Wang ${ }^{1}$, Zhenhai $\mathrm{Wu}^{1}$, Ling $\mathrm{Li}^{3}$, Chuhan Wang ${ }^{1}$, Hong $\mathrm{Li}^{1}{ }^{1, *}$, Xin Zhang ${ }^{1,2}$, Yingnan Zhang ${ }^{2}$, Junling $\mathrm{Li}^{1}$, Rui Gao ${ }^{1, *}$, Likun Xue ${ }^{2}$, Abdelwahid Mellouki ${ }^{4}$, Yangang Ren ${ }^{4}$, Qingzhu Zhang ${ }^{2}$

1. State Key Laboratory of Environmental Criteria and Risk Assessment, Chinese Research Academy of Environmental Sciences, Beijing 100012, China

2. Environment Research Institute, Shandong University, Qingdao 266237, China

3. Chongqing Research Academy of Eco-Environmental Sciences, Chongqing 401147, China

4. Institut de Combustion, Aérothermique, Réactivité et Environment (ICARE), CNRS (UPR 3021), Orléans 45071, France 
*Corresponding authors.

E-mail: lihong@craes.org.cn (Hong Li); gaorui@craes.org.cn (Rui Gao)

35

\section{Abstract}

Nitrous acid (HONO), as a key reservoir of hydroxyl radical $(\mathrm{OH})$, plays a significant role in atmospheric chemistry. To study the sources and atmospheric influence of $\mathrm{HONO}$, continuous observations of $\mathrm{HONO}$ and relevant air pollutants were performed from June to July 2019 at an urban site in Beijing. A comparative study on the ambient levels, diurnal variation, the sources in daytime and nighttime, and the formation mechanisms were investigated for a haze pollution period (Period I) and an ozone pollution period (Period II). The average hourly HONO concentrations during Period I, Period II, and the whole observation period, were $0.58 \pm 0.23,0.54 \pm 0.19$ and $0.44 \pm 0.24 \mathrm{ppb}$, respectively. The emission from vehicle exhaust was an important source of nocturnal HONO formation. During the nighttime, compared with the homogeneous reaction of $\mathrm{NO}$ with $\mathrm{OH}$, the heterogeneous conversion from $\mathrm{NO}_{2}$ was the dominant pathway for HONO formation. The heterogeneous conversion frequency was $0.0075 \mathrm{~h}^{-1}$ during Period I, higher than that during Period II $\left(0.0028 \mathrm{~h}^{-1}\right)$, suggesting a higher conversion potential to HONO formation during the haze episode. Based on the analysis of HONO budget, it was found that the daytime unknown source $\mathrm{P}_{\text {unknown }}$ 
for daytime HONO. Without HONO constraint, the Observation-Based Model (OBM) would largely underestimate the averaged daytime atmospheric oxidative capacity (24\%), $\mathrm{OH}$ production rate $(57 \%)$, and net $\mathrm{O}_{3}$ production rate $(20 \%)$. The study results further demonstrated the necessity for clarifying the formation mechanism of HONO to improve the understanding of the influence of $\mathrm{HONO}$ to atmospheric chemical processes.

Keywords: Nitrous acid (HONO); Haze pollution period; Ozone pollution period; Heterogeneous conversion; unknown daytime source; Observation-Based Model;

\section{Introduction}

Nitrous acid (HONO) is recognized as a significant precursor of the hydroxyl radical $(\mathrm{OH})$, the dominant oxidant in the atmosphere (Kleffmann 2007; Su et al. 2011; Villena et al. 2011). OH radicals can further initiate atmospheric photochemistry leading to the formation of ozone $\left(\mathrm{O}_{3}\right)$ and secondary organic aerosols (SOA) (Hofzumahaus et al., 2009). Previous studies showed that HONO could only be the source of $\mathrm{OH}$ in the early morning (Winer and Biermann, 1994), however, it had been found that $\mathrm{HONO}$ also contributed significantly (from $24 \%$ to $87 \%$ ) to $\mathrm{OH}$ production during the entire daytime (Acker et al., 2006b; Czader et al., 2012; Fu et al., 2019; Kleffmann et al., 2005; Li et al., 2018b; Ren et al., 2003; Su et al., 2008b; Yun et al., 2017). Therefore, the better understanding of the variations, sources, and formation mechanisms of HONO is critical for obtaining more clear idea of the atmospheric oxidation processes.

Many field measurements have been carried out at urban, rural, and remote sites in the world in the recent years, indicating that ambient HONO concentrations varied from several ppt in clean areas up to $15 \mathrm{ppb}$ in polluted areas (Elshorbany et al., 2009; Jia et al., 2020; Kang et al., 2006; Liu et al., 2020; Nakashima et al., 2017; Shi et al., 2020; Spataro and Ianniello, 2014; Spataro et al., 2013; Villena et al., 2011; Xue et al., 
2020; Yu et al., 2009b; Zhang et al., 2020; Zheng et al., 2020). Qin et al. (2009) measured a nocturnal maximum HONO concentration of $8.4 \mathrm{ppb}$ at an urban site in Guangzhou, with an unexpected high daytime concentration up to $2.0 \mathrm{ppb}$. In recent years, Spataro et al. (2013) observed a high level of HONO up to $9.71 \mathrm{ppb}$ in urban sites of Beijing. Fu et al. (2019) found that concentration of HONO reached $8 \mathrm{ppb}$ in a severe haze pollution episode in the Pearl River Delta of China. During a biomass burning period, overall high $\mathrm{HONO}$ concentrations ranging from $0.01 \mathrm{ppb}$ to $5.95 \mathrm{ppb}$ were observed at a suburban site in Nanjing (Nie et al., 2015). Even in the remote Arctic area, HONO concentrations ranging between 0.04 and 37.9 ppt had been reported (Spataro et al., 2017). Generally, different levels of HONO were observed under different environmental conditions.

As far as we know, the sources for atmospheric HONO are still not fully understood. The gas-phase reaction of $\mathrm{NO}$ and $\mathrm{OH}$ is once thought to be the only predominant source of HONO during the daytime. However, such a mechanism could not explain the observed much higher daytime HONO concentrations, implying some unknown sources existing. To explain the abnormal high daytime HONO, several sources of HONO have been proposed, including direct emissions from vehicle exhaust (Kurtenbach et al., 2001; Liu et al., 2017; Nakashima and Kajii, 2017), heterogeneous formation on wet surfaces (Han et al., 2016; Monge et al., 2010; Ren et al., 2020), soil nitrite emission (Su et al., 2011; Yang et al., 2020), particulate nitrate photolysis (Shi et al., 2020; Yang et al., 2018a; Ye et al., 2016; Zhang et al., 2020; Zheng et al., 2020) and conversion of nitric acid (Gall et al., 2016; Leong et al., 2016; Rutter et al., 2014; Ziemba et al., 2010). And the well-accepted new HONO source is the heterogeneous conversion of $\mathrm{NO}_{2}$ on humid surfaces (Ma et al., 2017). The uptake coefficient $(\gamma)$ relies on $\mathrm{NO}_{2}$ concentrations and various parameters including types of surfaces, relative humidity, surface-to-volume ratio (S/V), and surface water content (Finlayson-Pitts et al., 2003; Stutz et al., 2004; Stutz et al., 2002). Liu et al. (2014) calculated that the $\gamma$ value for aerosol uptake of $\mathrm{NO}_{2}$ could reach up to $\sim 10^{-4}$ in the afternoon when HONO lifetime is the shortest due to the photolysis, suggesting the significant role of aerosols as reaction media. 
In the past 10 years, some studies have been carried out on the ambient levels and formation mechanisms of HONO in China (Hendrick et al., 2014; Hou et al., 2016; Jia et al., 2020; Liu et al., 2020; Liu et al., 2014; Meng et al., 2020; Spataro et al., 2013; Wang et al., 2017; Yang et al., 2014; Zhang et al., 2019a; Zhang et al., 2019b; Zhang et al., 2020). However, most studies focused on the characteristic and source of HONO during the severe haze period, the HONO observations over the ozone pollution period were limited in China. In this study, we performed the high time-resolved observation of HONO in an urban site of Beijing in summer of 2019. In the following sections, we first compared the atmospheric levels and variations of HONO and related species during a haze pollution period and an ozone pollution period. Then, we explored several sources of HONO in the two typical cases. Finally, the impacts of HONO on atmospheric oxidative capacity (AOC), primary $\mathrm{OH}$ radical production, and $\mathrm{O}_{3}$ production rates were assessed.

\section{Experimental}

\subsection{Site description}

The observation campaign was conducted from 13 June to 4 July 2019. The observation site is on the roof (about $8 \mathrm{~m}$ above ground) of the Laboratory of Atmospheric Photochemical Simulation of Chinese Research Academy of Environmental Sciences (CRAES, $40.04^{\circ} \mathrm{N}, 116.42^{\circ} \mathrm{E}$ ), in the north of Chaoyang District of Beijing (Fig. S1). Chaoyang District is one of the six main urban districts (Haidian, Chaoyang, Dongcheng, Xicheng, Shijingshan and Fengtai) of Beijing and is located at the eastern area of Beijing. The CRAES site is to the north (about $2 \mathrm{~km}$ ) of the North Fifth Ring Road with high level of heavy traffic. It is located in a residential and commercial area, without obvious industrial pollution sources nearby (Cheng et al., 2018; Zhang et al., 2017). Thus, CRAES site could be considered as an urban site that can represent the urban environment of Beijing.

\subsection{Measurements}

\subsubsection{HONO measurement}


HONO was measured by an online commercial long path absorption photometer instrument (LOPAP-03, QUMA, Germany) by wet chemical sampling and photometric detection. A detailed description of the HONO instrument has been described previously (Li et al., 2012). Briefly, gaseous HONO are sampled by the absorption solution $(0.06 \mathrm{~mol} / \mathrm{L}$ sulfanilamide in $0.1 \mathrm{~mol} / \mathrm{L} \mathrm{HCl})$ in an external sampling unit. Then the solution can react with $0.4 \mathrm{mmol} / \mathrm{L} \mathrm{N}$-(1-naphthyl) ethylenediaminedihydrochloride solution to generate a stable diazonium salt which can be detected photo-metrically. The LOPAP is designed as a two-channel system to minimize potential interferences (e.g. PAN and $\mathrm{NO}_{2}+\mathrm{SO}_{2}$ ) (Heland et al., 2001). In channel 1, all HONO as well as the possible interferences are detected, while in channel 2 the same amount of interferences without HONO are quantified. The absorption spectra are recorded in $30 \mathrm{~s}$ intervals and the absorbance at $550 \mathrm{~nm}$ is used to evaluate the concentration of HONO. The sampled airflow is set to $1000 \mathrm{ml} / \mathrm{min}$. With the above settings, the HONO sampling efficiency is determined to be near $100 \%$. Calibration by using the known nitrite standard solution was performed every three or four days (Monday and Thursday) during the campaign. Zero measurements by sampling pure nitrogen were conducted automatically every 8 hours. The detection limit of the measurement is $4 \mathrm{ppt}$ with an accuracy of $10 \%$. The maximum detection limit is $2 \mathrm{ppm}$ and the observed HONO concentrations are within the range.

\subsubsection{Other measurements}

The $\mathrm{NO}, \mathrm{NO}_{2}$ and $\mathrm{NOx}$ concentrations were measured by a chemiluminescence instrument (Thermo 17i, USA) coupled with a molybdenum converter. It is noted that $\mathrm{NO}_{2}$ can be overestimated due to the potential conversion of other nitrogen-contained species (e.g., peroxyacetyl nitrate (PAN)). However, Xu et al. (2013) have reported that the overestimation was small at the urban sites affected by fresh emissions. Additionally, the interference was also considered to be small because of the weak photochemical reactions at night (Nie et al., 2015). The $\mathrm{O}_{3}$ concentration was monitored by a UV photometric $\mathrm{O}_{3}$ analyzer (Thermo 49i, USA). CO was monitored by the infrared absorption method using a CO analyzer (Thermo 48i, USA). Zero air was injected into the $\mathrm{CO}$ analyzer to check zero drift every night and calibrate the analyzer once the zero 
171 drift being bigger than $0.1 \mathrm{ppm}$. The $\mathrm{PM}_{2.5}$ mass concentration was detected by the model 5030 sharp $\mathrm{PM}_{2.5}$ monitor (Thermo, USA). Routine maintenance has been carried out to ensure the accuracy of these data. The detection limits for Model 17i, Model 49i, Model 48i, Model 5030 are $1.0 \mathrm{ppb}, 1.0 \mathrm{ppb}, 0.04 \mathrm{ppm}, 0.5 \mu \mathrm{g} / \mathrm{m}^{3}$, respectively.

The VOCs species were measured by an AirmoVOC online analyzer (Chromatotec Group, Bordeaux, France) with the flame ionization detectors (FID). Eighty-four VOCs species including 26 alkanes, 15 alkenes, 1 alkyne, 17 aromatic hydrocarbons, and 25 halogenated hydrocarbons were detected with a time resolution of 1 hour. Further detailed information could be found elsewhere (Cheng et al., 2018; Zhang et al., 2017). The carbonyl compounds were collected into 2,4dinitrophenylhydrazine (DNPH) coated silica cartridges (Agela Technologies, China) and analyzed by high-performance liquid chromatography (HPLC) based on the EPA TO-11A method (USEPA, 1999). The detailed procedures of sampling and analytical method can refer to our previous study (Zhang et al., 2019c). The carbonyl compounds were measured from 22 to 26 June 2019, and the sampling resolution was two hours during the campaign. Meteorological parameters consisting of wind speed (WS), wind direction (WD), temperature (T), and relative humidity (RH) were measured by an automatic weather station (MAWS301, Vaisala, Finland).

\subsection{Model simulation}

\subsubsection{Observation-based Model}

An Observation-Based Model (OBM) incorporating the nearly explicit chemical mechanism, Master Chemical Mechanisms (MCM, v3.3.1), has been widely employed in previous studies to dissect the atmospheric oxidative capacity (AOC) and the contributions of $\mathrm{HONO}$ to $\mathrm{OH}$ and $\mathrm{O}_{3}$ production (Jiang et al., 2020; Xue et al., 2016; Xue et al., 2014; Xue et al., 2013; Yang et al., 2018b; Yang et al., 2017). The MCM described the detailed degradation reactions of 143 primary VOCs and the latest inorganic reactions (Jenkin et al., 2003; Saunders et al., 2003). The heterogeneous chemistry processes, dry deposition and dilution mixing within the boundary layer are 
also included in the model. A more detailed description of this model configuration has been provided elsewhere (Xue et al., 2016; Xue et al., 2014; Xue et al., 2013). The model was constrained by the measured concentrations of $\mathrm{O}_{3}, \mathrm{SO}_{2}, \mathrm{CO}, \mathrm{NO}, \mathrm{NO}_{2}$, HONO, VOCs, carbonyls, $J_{\mathrm{NO} 2}, \mathrm{~T}, \mathrm{P}$ and $\mathrm{RH}$ at a time resolution of $5 \mathrm{~min}$. For VOCs and carbonyl compounds, which were not measured in real-time, the time-dependent data were linearly interpolated into $5 \mathrm{~min}$. Such approximation may lead to some uncertainties but should not significantly affect the estimation of the contribution of HONO to OH production (Jiang et al., 2020; Yang et al., 2018b).

Here our emphasis is placed on the computation of $\mathrm{AOC}, \mathrm{OH}$ production rates, and $\mathrm{O}_{3}$ budget. AOC is defined here as the sum of oxidation rates of VOCs and $\mathrm{CO}$ by the dominant atmospheric oxidants including $\mathrm{OH}, \mathrm{O}_{3}$, and $\mathrm{NO}_{3}$ (Xue et al., 2016). The major primary sources of $\mathrm{OH}$ production include photolysis of $\mathrm{O}_{3}, \mathrm{HONO}$, and OVOCs as well as reactions of $\mathrm{O}_{3}+$ VOCs (Jiang et al., 2020; Xue et al., 2016). The ozone formation rates refer to the formation rates of the total oxidant $\left(\mathrm{Ox}=\mathrm{O}_{3}+\mathrm{NO}_{2}\right)$ instead of $\mathrm{O}_{3}$ alone (Xue et al., 2014; Xue et al., 2013). The situ $\mathrm{O}_{3}$ photochemical formation mechanism can be clarified into three pathways, $\mathrm{HO}_{2}+\mathrm{NO}, \mathrm{CH}_{3} \mathrm{O}_{2}+\mathrm{NO}$, and other $\mathrm{RO}_{2}+\mathrm{NO}$ reactions. The $\mathrm{O}_{3}$ loss pathways include $\mathrm{NO}_{2}+\mathrm{OH}, \mathrm{RO}_{2}+\mathrm{NO}_{2}, \mathrm{O}_{3}+\mathrm{OH} / \mathrm{HO}_{2}$, $\mathrm{O}_{3}$ photolysis, and other reactions $\left(\mathrm{VOCs}+\mathrm{O}_{3}, \mathrm{VOCs}+\mathrm{NO}_{3}\right.$, Heter.loss $\left.\mathrm{N}_{2} \mathrm{O}_{5}\right)$. Considering the availability of carbonyls data, the model was only performed from 22 to 26 June (an ozone pollution period) with 00:00 local time (LT) as the initial time. Two model cases with and without HONO constraints were run to assess the role of $\mathrm{HONO}$ to $\mathrm{AOC}, \mathrm{OH}$ production rate, and ozone budget. A six-day pre-run was made to stabilize the unconstrained compounds and the final outputs were extracted to further analyses.

\subsubsection{Photolysis rates and $\mathrm{OH}$ concentration}

The photolysis rates of $\mathrm{HONO}$ and $\mathrm{O}\left({ }^{1} \mathrm{D}\right)$ were not measured directly in this work. The $J_{\mathrm{HONO}}$ and $J_{\mathrm{O} 1 \mathrm{D}}$ values can be calculated by the Tropospheric Ultraviolet and Visible (TUV) radiation model developed by the Nation Center for Atmospheric Research (NCAR) (http://www.acd.ucar.edu/TUV). To reflect the influence of aerosols on $J_{\mathrm{HONO}}$ and $J_{\mathrm{O} 1 \mathrm{D}}$ values, aerosol vertical optical depth (AOD), single scattering albedo (SSA), 
and angstrom exponent values $(\alpha)$ were input into the TUV model. The AOD, $\alpha, \mathrm{O}_{3}$ column concentration, and cloud optical thickness were determined by Moderate Resolution Imaging Spectroradiometer (MODIS) satellite (https://neo.sci.gsfc.nasa.gov/blog/). In our work, the value of 0.91 was used as SSA for the Beijing summer period (Spataro et al., 2013; Yu et al., 2009a).

As $\mathrm{OH}$ concentration is not available in our study, the daytime $\mathrm{OH}$ concentration can be estimated by using the empirical power-law Eq. (1) (Rohrer and Berresheim, 2006) below:

$$
\begin{gathered}
{[\mathrm{OH}]=\mathrm{a} \times\left(J_{\mathrm{O} 1 \mathrm{D}} / 10^{-5} \mathrm{~s}^{-1}\right)^{\mathrm{b}}+\mathrm{c}} \\
\left(\mathrm{a}=4.2 \times 10^{6} \mathrm{~cm}^{-3}, \mathrm{~b}=1.0, \mathrm{c}=0.6 \times 10^{6} \mathrm{~cm}^{-3}\right)
\end{gathered}
$$

Where $[\mathrm{OH}]$ represents the $\mathrm{OH}$ concentration, $J_{\mathrm{O} 1 \mathrm{D}}$ is the photolysis frequencies of $\mathrm{O}^{1} \mathrm{D}$ modelled by the TUV model. The daytime $\mathrm{OH}$ concentration ranged from 6.5 $\times 10^{5}$ to $9.2 \times 10^{6}$ molecule $\mathrm{cm}^{-3}$ with the mean value of $4.4 \times 10^{6}$ molecule $\mathrm{cm}^{-3}$, which is within the range of those measured in Beijing (Lu et al., 2014; Tan et al., 2018). The correlations between the daytime calculated $\mathrm{OH}$ concentrations and the modelled concentrations by the OBM from 22 to 26 June were displayed in Fig. S2. The good correlations $\left(\mathrm{R}^{2}=0.88\right)$ showed the reliability of the $\mathrm{OH}$ concentrations calculated by the empirical power-law equation.

\section{Results and discussion}

\subsection{Overview of measurements}

The time series of $\mathrm{HONO}, \mathrm{O}_{3}, \mathrm{CO}, \mathrm{NO}, \mathrm{NO}_{2}, \mathrm{PM}_{2.5}$ and meteorological parameters from 13 June to 4 July are displayed in Fig. 1. During the observation period, the temperature ranged from 18 to $38^{\circ} \mathrm{C}$, with average values of $28 \pm 4^{\circ} \mathrm{C}$; the $\mathrm{RH}$ ranged from $16 \%$ to $92 \%$, with average values of $52 \pm 18 \%$. The wind direction during the observation period was dominated by the south wind and the average WS was $2.73 \pm 1.65 \mathrm{~m} / \mathrm{s}$. Occasionally on 29 and 30 June, the dominant wind direction was north, and the hourly WS exceeded $7 \mathrm{~m} / \mathrm{s}$.

The average hourly levels of $\mathrm{NO}, \mathrm{NO}_{2}$, and $\mathrm{CO}$ were $2.7 \pm 1.9 \mathrm{ppb}(1.0-14.2 \mathrm{ppb})$, 
15.5 $\pm 8.8 \mathrm{ppb}(1.7-54.5 \mathrm{ppb})$, and $1.20 \pm 0.32 \mathrm{ppm}(0.47-2.57 \mathrm{ppm})$, respectively. The levels of $\mathrm{PM}_{2.5}$ and $\mathrm{O}_{3}$ ranged from 5.5 to $125.1 \mu \mathrm{g} / \mathrm{m}^{3}$ and from 1.0 to $157.7 \mathrm{ppb}$, and averaged at $41.6 \pm 26.8 \mu \mathrm{g} / \mathrm{m}^{3}$ and $61.3 \pm 35.4 \mathrm{ppb}$, respectively. The measured hourly concentrations of HONO ranged from 0.10 to $1.39 \mathrm{ppb}$, with an average of $0.44 \pm 0.24$ ppb. The highest HONO concentration in the present study was comparable to the level reported in a northwestern urban area of Beijing (Wang et al., 2017), but lower than the levels in other urban areas in China, such as Beijing (3.24 ppb, (Hou et al., 2016); 3.69 ppb, (Spataro et al., 2013)), Xi'an (4.3 ppb, (Huang et al., 2017)), Shanghai (5.84 ppb, (Cui et al., 2018)), and Hong Kong (13.9 ppb, (Yun et al., 2017)).

Based on the National Ambient Air Quality Standard (NAAQS) (GB 3095-2012), only a haze day (19 June) occurred with daily $\mathrm{PM}_{2.5}$ concentrations exceeding the Grade II of NAAQS $\left(75 \mu \mathrm{g} / \mathrm{m}^{3}\right.$ ). Seventeen $\mathrm{O}_{3}$ non-attainment days (except 14, 16, 29-30 June and 1 July) occurred with daily maximum-8h average concentrations exceeding the Grade II of NAAQS (75 ppb, corresponding to $160 \mu \mathrm{g} / \mathrm{m}^{3}$ ). In this study, a haze pollution period from 17 to 21 June (Period I, the blue area in Fig. 1) and an ozone pollution period from 22 to 26 June (Period II, the orange area in Fig. 1) were selected as two typical case studies. Table 1 documented the average hourly $\mathrm{HONO}, \mathrm{NO}_{2}, \mathrm{NO}$, $\mathrm{PM}_{2.5}, \mathrm{O}_{3}$ concentrations, and $\mathrm{HONO} / \mathrm{NO}_{2}$ ratio during the two periods. Given that the NOx analyzer probably overestimated the $\mathrm{NO}_{2}$ concentrations, the $\mathrm{HONO} / \mathrm{NO}_{2}$ ratios discussed in Section 3 are lower limits for the values. The average hourly HONO level during Period I $(p<0.05)$ was higher than that during Period II. The result of higher HONO level during Period I was consistent with the previous studies (Cui et al., 2018; Zhang et al., 2019b). The average hourly ozone levels were similar in two periods. Compared with that during Period II, a higher $\mathrm{HONO} / \mathrm{NO}_{2}$ ratio was found during Period I. The $\mathrm{HONO} / \mathrm{NO}_{2}$ ratio was often applied to assess the contribution of $\mathrm{NO}_{2}$ to HONO from the heterogeneous conversion ( $\mathrm{Li}$ et al., 2012). It implied that the heterogeneous conversion from $\mathrm{NO}_{2}$ might contribute to $\mathrm{HONO}$ formation.

The averaged daytime and nighttime $\mathrm{HONO}, \mathrm{NO}_{2}$ and $\mathrm{HONO} / \mathrm{NO}_{2}$ of our observation and other urban sites were summarized in Table S1. The higher HONO, $\mathrm{NO}_{2}$, and $\mathrm{HONO} / \mathrm{NO}_{2}$ levels occurred at nighttime in all sites except Nanjing (Liu et 
290 al., 2019) and Hong Kong (Xu et al., 2015). The average nighttime HONO/NO 2 ratios 291 obtained by this study were lower than those in previous results of Beijing (Jia et al., 292 2020; Tong et al., 2015), but comparable to measurements at Shanghai (Bernard et al., 293 2016), Hong Kong (Xu et al., 2015), Roma (Acker et al., 2006a), and Paris (Michoud 294 et al., 2014). The lower $\mathrm{HONO} / \mathrm{NO}_{2}$ ratios may suggest a less conversion from $\mathrm{NO}_{2}$ to 295 HONO formation in this study. 

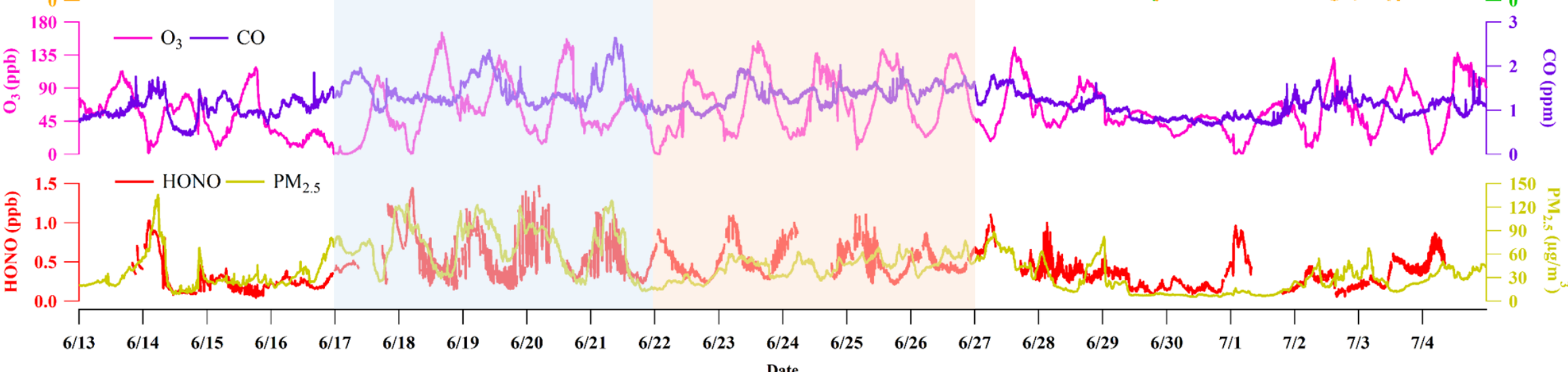

Fig. 1 Time series of $\mathrm{HONO}, \mathrm{O}_{3}, \mathrm{CO}, \mathrm{NO}, \mathrm{NO}_{2}, \mathrm{PM}_{2.5}$, and meteorological parameters from 13 June to 4 July 2019. Blue and orange areas are Period I (haze pollution) and II (ozone pollution), respectively. (Missing data are due to instrument maintenance) 


\begin{tabular}{cccc}
\hline Pollutant & Unit & $\begin{array}{c}\text { Period I } \\
\text { Haze pollution period }\end{array}$ & $\begin{array}{c}\text { Period II } \\
\text { Ozone pollution period }\end{array}$ \\
\hline $\mathrm{HONO}$ & $\mathrm{ppb}$ & $0.58 \pm 0.26(0.25-1.39)$ & $0.54 \pm 0.19(0.24-1.04)$ \\
$\mathrm{NO}_{2}$ & $\mathrm{ppb}$ & $16.4 \pm 6.5(7.4-38.7)$ & $18.5 \pm 8.0(6.1-44.0)$ \\
$\mathrm{NO}$ & $\mathrm{ppb}$ & $3.6 \pm 2.5(1.3-14.2)$ & $2.6 \pm 1.5(1.2-11.4)$ \\
$\mathrm{PM}_{2.5}$ & $\mu \mathrm{g} / \mathrm{m}^{3}$ & $69.5 \pm 29.7(13.6-123.3)$ & $43.5 \pm 13.4(15.0-72.9)$ \\
$\mathrm{O}_{3}$ & $\mathrm{ppb}$ & $62.9 \pm 39.4(1.0-157.7)$ & $73.2 \pm 43.4(1.0-145.0)$ \\
$\mathrm{HONO} / \mathrm{NO}_{2}$ & $\%$ & $3.8 \pm 1.6(1.4-9.2)$ & $3.1 \pm 0.9(1.4-5.8)$ \\
\hline
\end{tabular}

Table 1 Average hourly $\mathrm{HONO}, \mathrm{NO}_{2}, \mathrm{NO}, \mathrm{PM}_{2.5}, \mathrm{O}_{3}$ concentrations, and $\mathrm{HONO} / \mathrm{NO}_{2}$ ratios during the haze pollution period and the ozone pollution period
301

302 303 304 305 306 307 308 309 310 311 312 313 314 315 316 317 318 319

\subsection{Diurnal variations of $\mathrm{HONO}$}

The diurnal profiles of $\mathrm{HONO}, \mathrm{NO}_{2}, \mathrm{O}_{3}$, and $\mathrm{HONO} / \mathrm{NO}_{2}$ ratio were illustrated in Fig. 2. The obvious diurnal variation of HONO resembled those at other urban sites in previous studies (Huang et al., 2017; Li et al., 2018a; Michoud et al., 2014; Wang et al., 2017). After sunrise, HONO concentration dropped rapidly to $\sim 0.33 \mathrm{ppb}$ at noon due to photolysis and the elevated height of the boundary layer, the concentration of which remained at a low level until sunset. Then HONO concentration increased and accumulated during the night, reaching the peak value of $0.71 \mathrm{ppb}$ at 04:00 LT. The diurnal cycle of $\mathrm{NO}_{2}$ was similar to that of $\mathrm{HONO}$. After sunset, $\mathrm{NO}_{2}$ increased and maintained at a high level during the night. A maximum value of $23.0 \mathrm{ppb}$ was also obtained at 04:00 LT. The diurnal cycle of $\mathrm{O}_{3}$ was opposite to $\mathrm{HONO}$ and $\mathrm{NO}_{2}$, with a maximum value of 101.7 $\mathrm{ppb}$ at 15:00 LT and a minimum value of 24.6 ppb at 04:00 LT. The $\mathrm{HONO} / \mathrm{NO}_{2}$ ratio started to increase gradually after sunset and reached the first weak peak during the night (04:00 LT). The ratio had a second rising process after 09:00 LT and climbed to the maximum at 13:00 LT. The values of $\mathrm{HONO} / \mathrm{NO}_{2}$ at noon $(11: 00-$ 16:00 LT) were even higher than those during the night. If the sources of HONO were the same during the night and day, a low $\mathrm{HONO} / \mathrm{NO}_{2}$ ratio should be obtained at noon because of the strong photolysis of HONO. Thus, we can conclude the existence of an 
additional source of HONO during the daytime, and further discuss the potential daytime source of HONO in Section 3.4.
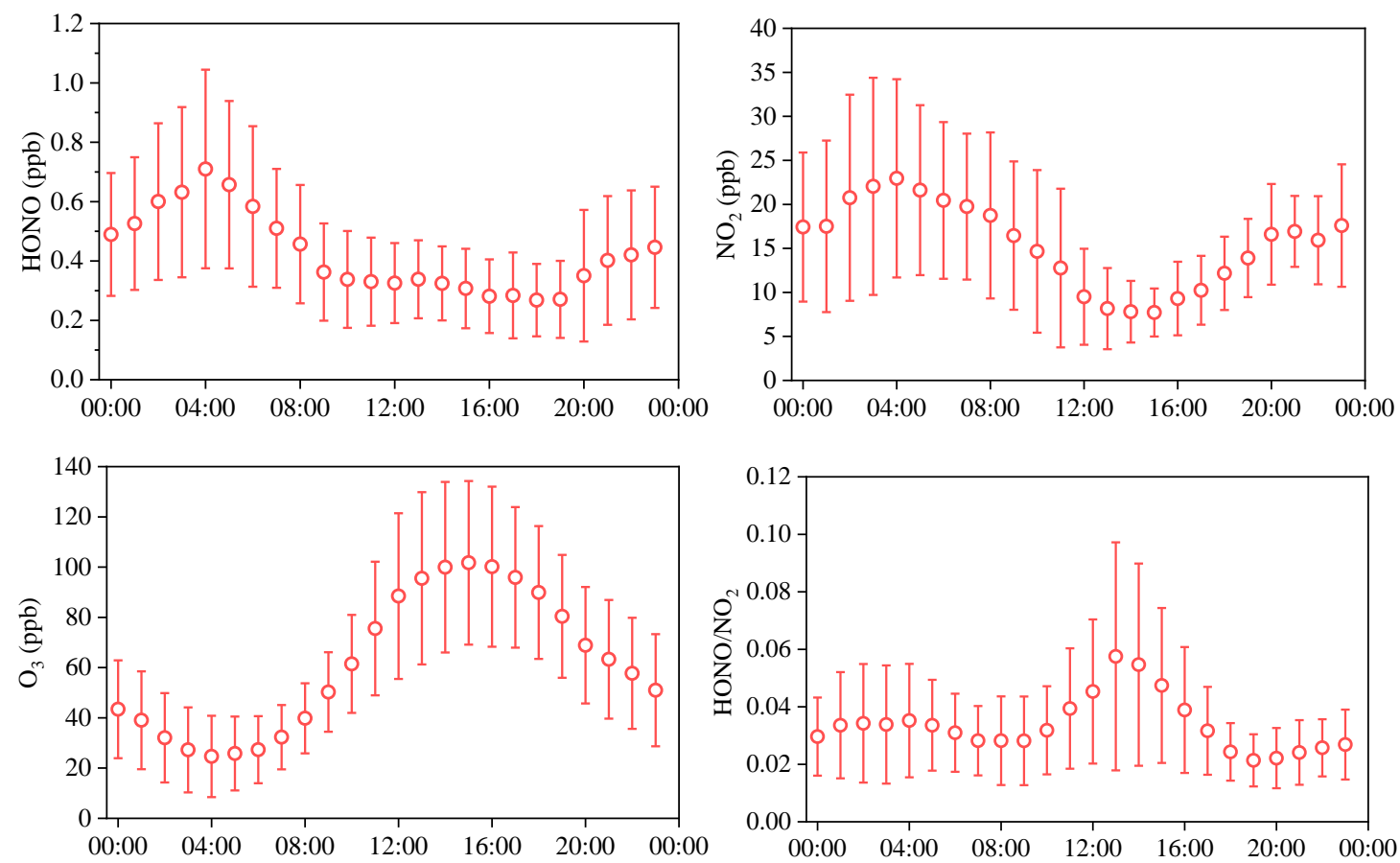

Fig. 2 Diurnal profiles of $\mathrm{HONO}, \mathrm{NO}_{2}, \mathrm{O}_{3}$, and $\mathrm{HONO} / \mathrm{NO}_{2}$ ratio (error bar means standard deviation)

\subsection{Nocturnal HONO sources}

\subsubsection{Direct vehicle emission}

Previous studies have shown that HONO can be directly emitted into the atmosphere by combustion processes including vehicle exhaust and biomass burning (Burling et al., 2010; Spataro and Ianniello, 2014). As our sampling site is close to the five-ring road with high traffic volume, it is essential to assess the contribution of vehicle emission to ambient $\mathrm{HONO}$ concentrations. The HONO/NOx ratio was usually used to derive the emission factor of $\mathrm{HONO}$ in the freshly emitted air masses (Kurtenbach et al., 2001). A criterion of NO/NOx > 0.7 was often adopted to select the fresh air masses. However, in our study the relatively low NO/NOx ratio (from 0.09 to 0.53) suggested that the air mass had become aged before arriving at the sampling site. The HONO/NOx ratios of 0.0065 (Spataro et al., 2013; Tong et al., 2015) and 0.008 (Jia et al., 2020; Meng et al., 2020; Zhang et al., 2020) have been chosen as the emission 
340 factor for the urban area of Beijing in previous studies. Based on the tunnel studies 341 (Kleffmann et al., 2003; Kurtenbach et al., 2001), the ratios ranging from $0.3 \%$ to $0.8 \%$ 342 in fresh vehicle exhaust had been reported. Thus, the values of $0.003,0.0065$ and 0.008 343 were adopted to estimate the contribution from traffic emission. The directly emitted 344 HONO concentration can be calculated by Eq. (2) below:

$$
[\mathrm{HONO}]_{\mathrm{emis}}=[\mathrm{NOx}] \times \mathrm{F}
$$

346 where, $[\mathrm{HONO}]_{\mathrm{emis}}$ represents the HONO levels from the traffic emission, [NOx] 347 represents the NOx concentration, and F represents the emission factor. To avoid the 348 influence of HONO photolysis, only the nocturnal data from 20:00 LT to the next 06:00 349 LT were considered. The statistical results of the ratios of $[\mathrm{HONO}]_{\mathrm{emis}} /[\mathrm{HONO}]$ were 350 shown in Fig. S3. The average calculated [HONO] $]_{\text {emis }}$ levels contributed 15\%, 31\%, 351 and $40 \%$ to the whole measured nocturnal HONO levels at the emission factor of 0.003 , 3520.0065 and 0.008 , respectively. In previous studies, the contributions from vehicle 353 emission ranged between $20.59 \%$ and $52 \%$ in urban areas of Beijing (Spataro et al., 2013; Tong et al., 2015; Zhang et al., 2019b). Therefore, direct emissions from vehicles could be an important HONO source in Beijing.

\subsection{2 $\mathrm{NO}+\mathrm{OH}$ homogeneous formation}

The reaction of $\mathrm{NO}$ with $\mathrm{OH}$ was also anticipated as a dominant homogeneous production of HONO in nighttime (Li et al., 2012; Lu et al., 2014). Considering the reactions of $\mathrm{R} 1$ and $\mathrm{R} 2$, the net homogeneous $\mathrm{HONO}$ production $\left(\mathrm{P}^{\text {net }} \mathrm{OH}+\mathrm{NO}\right.$ ) can be calculated by the following Eq. (3):

$$
\begin{array}{cc}
\mathrm{NO}+\mathrm{OH} \rightarrow \mathrm{HONO} & \mathrm{R} 1 \\
\mathrm{HONO}+\mathrm{OH} \rightarrow \mathrm{NO}_{2}+\mathrm{H}_{2} \mathrm{O} & \mathrm{R} 2 \\
\mathrm{P}_{\mathrm{NO}+\mathrm{OH}}^{\text {net }}=k_{\mathrm{NO}+\mathrm{OH}}[\mathrm{OH}][\mathrm{NO}]-k_{\mathrm{HONO}+\mathrm{OH}[\mathrm{HONO}][\mathrm{OH}]}
\end{array}
$$

where the rate constants $k_{\mathrm{NO}+\mathrm{OH}}$ and $k_{\mathrm{HONO}+\mathrm{OH}}$ are $7.2 \times 10^{-12}$ and $5.0 \times 10^{-12} \mathrm{~cm}^{3}$ molecule ${ }^{-1} \mathrm{~s}^{-1}$ for reactions R1 and R2 at $298 \mathrm{~K}$, respectively (Li et al., 2012); [NO] and [HONO] represents concentrations of NO and HONO, respectively. Since the rate constants of $\mathrm{R} 1$ and $\mathrm{R} 2$ are similar, the $\mathrm{P}^{\text {net }} \mathrm{NO}+\mathrm{OH}$ is determined by $\mathrm{NO}$ and $\mathrm{HONO}$ concentrations. The nighttime $\mathrm{OH}$ concentration with $5 \times 10^{5}$ molecules $\mathrm{cm}^{-3}$ was 
369 observed by Tan et al. (2017) in Wangdu in summer 2014. An average value of $5.0 \times$ $37010^{5}$ molecules $\mathrm{cm}^{-3}$ was assumed to the nighttime $\mathrm{OH}$ concentration of Beijing in this 371 study (Cui et al., 2018; Huang et al., 2017; Spataro et al., 2013; Tong et al., 2015).
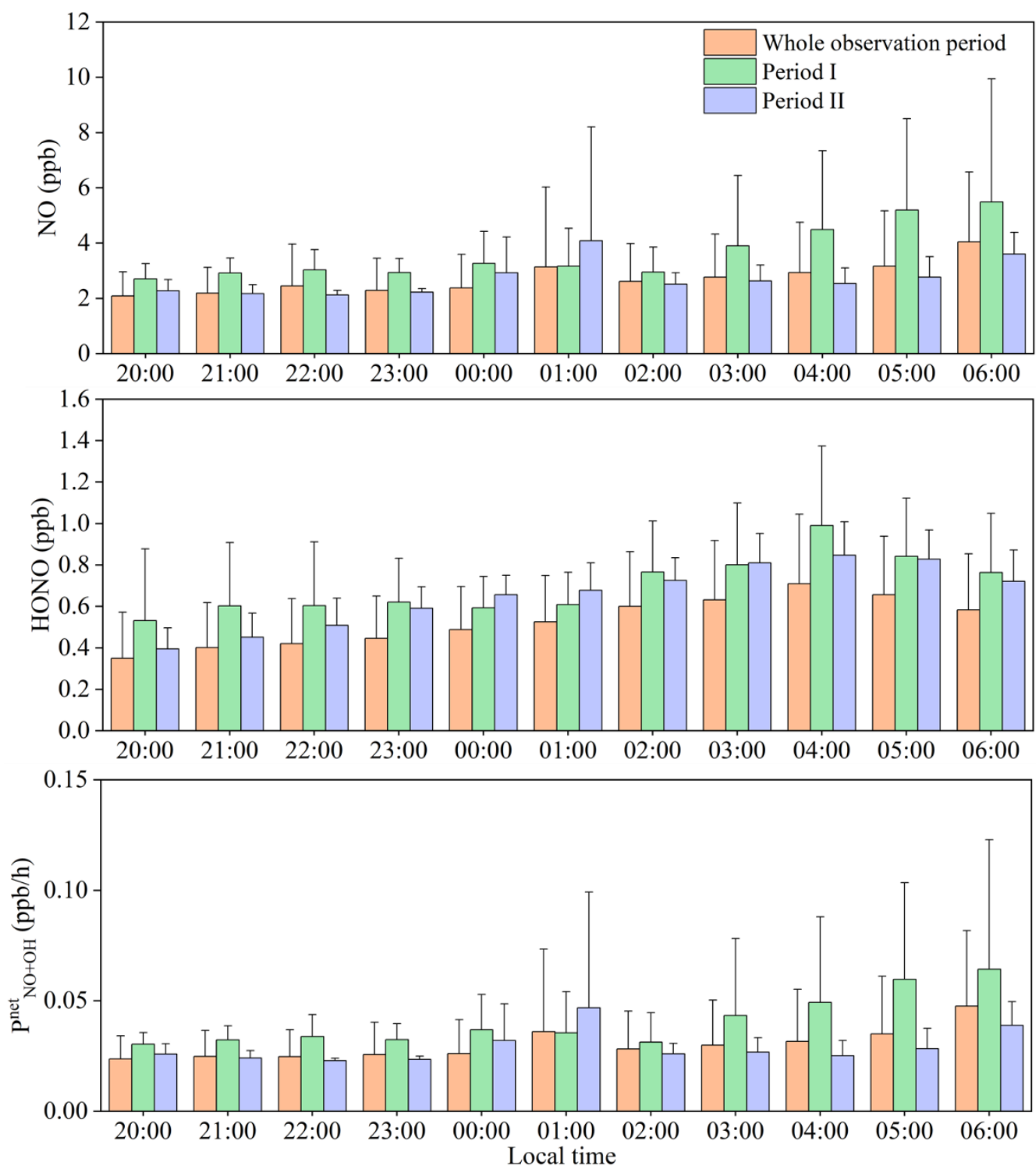

Fig. 3 depicted the nocturnal variations of $\mathrm{NO}, \mathrm{HONO}$, and $\mathrm{P}^{\text {net }} \mathrm{NO}+\mathrm{OH}$ during the 378 whole observation period, Period I, and Period II. Before midnight (20:00-00:00), the 379 relatively low $\mathrm{NO}$ and $\mathrm{HONO}$ concentrations provided the low $\mathrm{P}^{\text {net }} \mathrm{NO}+\mathrm{OH}$ values of 
$0.03 \pm 0.01 \mathrm{ppb} \mathrm{h}^{-1}$ during the three periods. After midnight (01:00-06:00), the $\mathrm{P}^{\text {net }} \mathrm{NO}+\mathrm{OH}$ values during the three periods showed increase trends due to the increases of NO and HONO concentrations, averaged at $0.03 \pm 0.03,0.05 \pm 0.03$ and $0.03 \pm 0.01 \mathrm{ppb} \mathrm{h}^{-1}$, respectively. Note that the $\mathrm{P}_{\mathrm{NO}}^{\mathrm{net}} \mathrm{OH}$ value averaged at $0.04 \pm 0.02 \mathrm{ppb} \mathrm{h}^{-1}$ during Period I were slightly higher than those during the whole observation period $(0.03 \pm 0.02 \mathrm{ppb}$ $\left.\mathrm{h}^{-1}\right)$ and Period II $\left(0.03 \pm 0.01 \mathrm{ppb} \mathrm{h}^{-1}\right)$. The calculated average $\mathrm{P}_{\mathrm{NO}+\mathrm{OH}}^{\text {net }}$ ranged from 0.002 to $0.17 \mathrm{ppb} \mathrm{h}^{-1}$, which was comparable to those obtained at an urban site of Western China in summer (0.04-0.15 pp h $^{-1}$ ) (Huang et al., 2017), but lower than the results in severe haze periods in urban Beijing (0.98-2.18 $\mathrm{ppb} \mathrm{h}^{-1}$ ) (Tong et al., 2015; Zhang et al., 2019b).

\subsubsection{Heterogeneous conversion of $\mathrm{NO}_{2}$}

Numerous field measurements in urban sites reported that heterogeneous conversion reaction of $\mathrm{NO}_{2}$ on wet surfaces could be an important $\mathrm{HONO}$ source at night in the atmosphere (Sorgel et al., 2011; Spataro et al., 2013; Su et al., 2008a). The $\mathrm{NO}_{2}$ conversion efficiency mainly depends on the surface properties. The positive correlation between $\mathrm{HONO}$ and $\mathrm{NO}_{2}\left(\mathrm{R}^{2}=0.31\right.$, shown in Fig. S4) was also found in this study, implying that $\mathrm{NO}_{2}$ might be a precursor of $\mathrm{HONO}$ production (Huang et al., 2017; Qin et al., 2009).

The aerosol surface is considered as an important media for the heterogeneous conversions of $\mathrm{NO}_{2}$ in several studies (Huang et al., 2017; Li et al., 2012; Liu et al., 2014). As aerosol surface density is not measured, $\mathrm{PM}_{2.5}$ concentrations are used as surrogates to identify the influences of aerosols on HONO formation. Fig. 4(a) showed the correlation of $\mathrm{HONO} / \mathrm{NO}_{2}$ with $\mathrm{PM}_{2.5}$ concentrations at night, and the positive correlation revealed the heterogeneous conversions of $\mathrm{NO}_{2}$ on aerosol surfaces. Additionally, it can be seen that the mean $\mathrm{HONO} / \mathrm{NO}_{2}$ value increased gradually with the increasing $\mathrm{PM}_{2.5}$ concentrations. The correlations between $\mathrm{HONO} / \mathrm{NO}_{2}$ and $\mathrm{PM}_{2.5}$ concentrations at night during Period I and Period II were displayed in Fig. S5. A higher correlation was found in Period I, indicating the possibility of a higher conversion frequency on aerosol surfaces in the haze pollution period than in the clean period. The effects of $\mathrm{RH}$ on the heterogeneous formation of HONO are further 
410 investigated. Stutz et al. (2004) asserted that the absorbed water on the surface 411 participated in the heterogeneous conversion of $\mathrm{NO}_{2}$ to $\mathrm{HONO}$. The influence of $\mathrm{RH}$ 412 on heterogeneous HONO formation at night was illustrated in Fig. 4(b). An increase of $413 \mathrm{HONO} / \mathrm{NO}_{2}$ along with the increasing $\mathrm{RH}$ was found when the $\mathrm{RH}$ was less than $60 \%$. 414 Further increase $(>60 \%)$ of $\mathrm{RH}$ led to a decrease of the $\mathrm{HONO} / \mathrm{NO}_{2}$ value. This 415 phenomenon can be associated with the number of water layers formed on aerosol 416 surfaces. The excess water on the surface is a limiting factor for the $\mathrm{NO}_{2}$ conversion. 417 When the RH is larger than $60 \%$ in this study, the heterogeneous conversion efficiency 418 seems to be depended negatively on RH. The similar phenomenon was also observed 419 by $\mathrm{Yu}$ et al. (2009b) in Nepal, Li et al. (2012) and Wang et al. (2013) in China. 420 Additionally, the water uptake processes could occur on aerosol/ground surfaces. Many 421 studies have reported that the water droplets act as a role in the HONO sink when the 422 RH exceeds 96\% (Acker et al., 2005; He et al., 2006; Yu et al., 2009b; Zhou et al., 2007). 423 Since the maximum $\mathrm{RH}$ is $92 \%$ in this study, the process of HONO uptake by water is 424 not considered.

425 The conversion frequency $\left(C_{\mathrm{HONO}}\right)$ is widely used to estimate the conversion rate 426 from $\mathrm{NO}_{2}$. It was assumed that all measured $\mathrm{HONO}$ came from heterogeneous

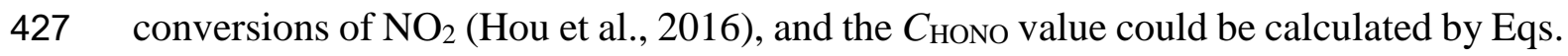
428 (4) and (5) (Su et al. 2008a; Wang et al. 2017a; Zhang et al. 2019b). To eliminate the 429 influence of direct vehicle emission, the HONO concentration was corrected by Eq. (6) 430 and was denoted as $[\mathrm{HONO}]_{\text {corr. }}$

$$
\begin{aligned}
& C_{\text {HONO }}^{X}=\frac{2\left(\frac{[\text { HONOcorr }]_{t 2}}{[X]_{t 2}} \times[\bar{X}]-\frac{[\text { HONOcorr }]_{t 1}}{[X]_{t 1}} \times[\bar{X}]\right)}{\left(t_{2}-t_{1}\right)\left(\frac{\left[N O_{2}\right]_{t 2}}{[X]_{t 2}} \times[\bar{X}]+\frac{\left[N O_{2}\right]_{t 1}}{[X]_{t 1}} \times[\bar{X}]\right)} \\
& =\frac{2\left(\frac{\left[\text { HONOCorr }_{t 2}\right.}{[X]_{t 2}}-\frac{\left[\text { HONOCorr }_{t 1}\right.}{[X]_{t 1}}\right)}{\left(t_{2}-t_{1}\right)\left(\frac{\left[N O_{2}\right]_{t 2}}{[X]_{t 2}}+\frac{\left[N O_{2}\right]_{t 1}}{[X]_{t 1}}\right)} \\
& C_{\mathrm{HONO}}=\frac{1}{3}\left(C_{\mathrm{HONO}}^{0}+C_{\mathrm{HONO}}^{\mathrm{CO}}+C_{\mathrm{HONO}}^{\mathrm{NO}}\right) \\
& {[\mathrm{HONO}]_{\mathrm{corr}}=[\mathrm{HONO}]-[\mathrm{HONO}]_{\mathrm{emis}}}
\end{aligned}
$$

435 where $\left[\mathrm{HONO}_{\text {corr }}\right]_{\mathrm{t}},\left[\mathrm{NO}_{2}\right]_{\mathrm{t}}$ and $[\mathrm{X}]_{\mathrm{t}}$ represents the concentrations of the $\mathrm{HONO}_{\text {corr }}, \mathrm{NO}_{2}$ 436 and reference gases at the time t, respectively. $[\bar{X}]$ is the averaged reference gases 
437 concentration during the time interval of $\mathrm{t}_{1}$ and $\mathrm{t}_{2}$. $C_{\text {HONO }}^{X}$ is the conversion frequency 438 scaled with reference gases $\mathrm{X}\left(\mathrm{CO}\right.$ and $\left.\mathrm{NO}_{2}\right)$ and $C_{H O N O}^{0}$ is the conversion frequency 439 which is not scaled. The emission factor is 0.0065 . The heterogeneous conversion rates 440 of $\mathrm{NO}_{2}$ were $0.0036 \mathrm{~h}^{-1}, 0.0075 \mathrm{~h}^{-1}$, and $0.0028 \mathrm{~h}^{-1}$ on average during the whole 441 observation period, Period I and Period II, respectively. The rates were comparable to 442 the values of $0.0039 \mathrm{~h}^{-1}$ in winter of Beijing in 2014 (Hou et al., 2016), $0.0058 \mathrm{~h}^{-1}$ in 443 winter of 2016 (Zhang et al., 2019b), and $0.0078 \mathrm{~h}^{-1}$ in autumn of 2018 (Jia et al., 2020), 444 but lower than the values obtained in other studies of Beijing, such as $0.010 \mathrm{~h}^{-1}$ in 445 summer of 2016 (Wang et al., 2017) and $0.016 \mathrm{~h}^{-1}$ in spring of 2018 (Zhang et al., 2020). 446 Based on the study of Su et al. (2008a), the conversion rates could be affected by several 447 factors including surface features, aerosol concentrations, and the environments. The 448 discrepancies may be related to the different types of surface and aerosol concentrations 449 in different environments. A heterogeneous production rate of $\mathrm{HONO}$ at night $\left(C_{\mathrm{HONO}}\right.$ $\left.450 \times\left[\mathrm{NO}_{2}\right]\right)$ of $0.06 \mathrm{ppb} \mathrm{h}^{-1}$ was derived during the whole observation period, which is 451 higher than the rate from homogeneous reaction of $\mathrm{NO}$ with $\mathrm{OH}$. This showed that the 452 heterogeneous conversion from $\mathrm{NO}_{2}$ was more important for $\mathrm{HONO}$ formation at night 453 during the observation period.
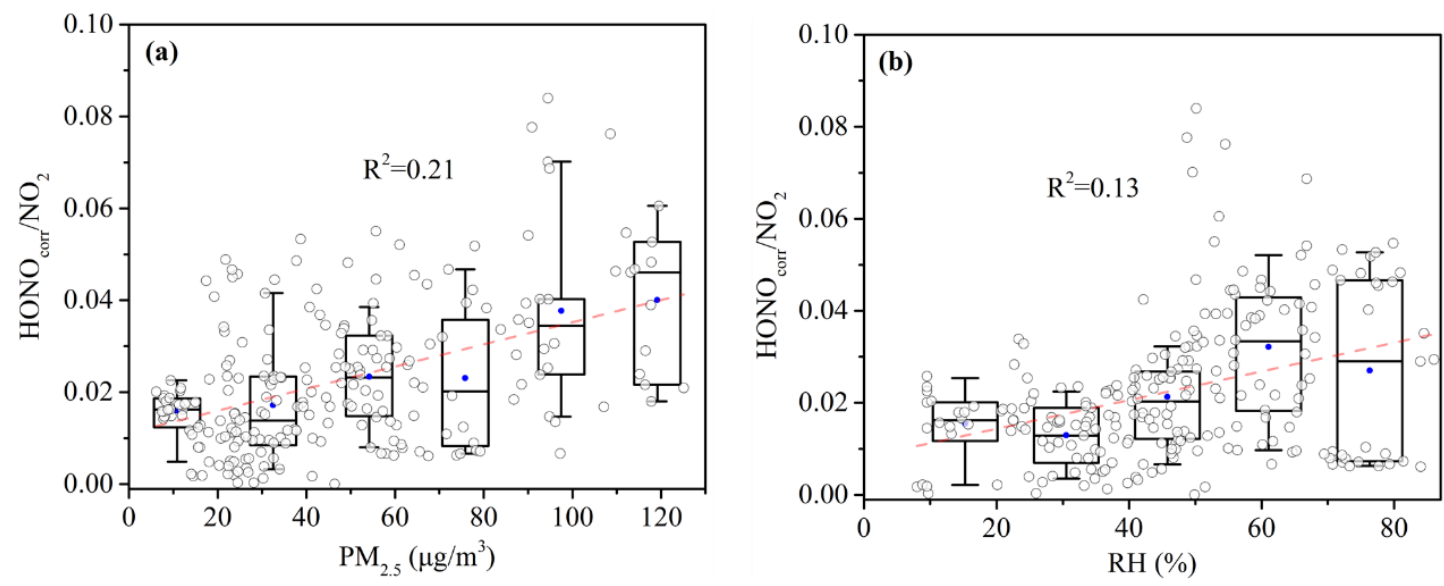

455 456 457 458

Fig. 4 The correlations between $\mathrm{HONO}_{\text {corr }} \mathrm{NO}_{2}$ and $\mathrm{PM}_{2.5}$ concentration (a) and $\mathrm{RH}$ (b) at night. Mean (blue circle), median (middle horizontal line), 25th and 75th percentiles (P25-P75, box), 10th and 90th percentiles (P10-P90, whiskers). 


\subsection{Daytime HONO budget}

Several studies reported that the gas phase reaction of $\mathrm{OH}$ and $\mathrm{NO}$ was not sufficient to explain the HONO concentration in the daytime. An unknown daytime HONO source needs to be identified. Based on the source and sink pathways of HONO, the net daytime HONO formation rate can be calculated by a detailed budget Eq. (7)(9) (Jia et al., 2020; Sorgel et al., 2011).

$$
\begin{aligned}
\frac{d[\mathrm{HONO}]}{d t}=P_{\text {emis }}+P_{\mathrm{OH}+\mathrm{NO}}+P_{\text {unknown }}-L_{\mathrm{HONO}+\mathrm{OH}}-L_{p h o}-L_{d e p} \\
\mathrm{~L}_{\mathrm{pho}}=J_{\mathrm{HONO}} \times[\mathrm{HONO}] \\
\mathrm{L}_{\mathrm{dep}}=\mathrm{V}_{\mathrm{d}} \times[\mathrm{HONO}] / \mathrm{H}
\end{aligned}
$$

where, $\mathrm{d}[\mathrm{HONO}] / \mathrm{dt}$ means the variation of the observed HONO concentrations; $\mathrm{P}_{\text {emis, }}$, $\mathrm{P}_{\mathrm{OH}+\mathrm{NO}}$, and $\mathrm{P}_{\text {unknown }}$ represent the contribution rates of direct vehicle emission, the homogeneous reaction of $\mathrm{OH}$ and $\mathrm{NO}$ and the unknown source, respectively. $\mathrm{L}_{\mathrm{HONO}+\mathrm{OH}}$, $\mathrm{L}_{\text {pho, }}$ and $\mathrm{L}_{\mathrm{dep}}$ donate the loss rate of the reaction of $\mathrm{HONO}$ with $\mathrm{OH}$, the photolysis reaction of $\mathrm{HONO}$, and the dry deposition of $\mathrm{HONO}$, respectively. $J_{\mathrm{HONO}}$ is the photolysis frequency of HONO obtained by the TUV model simulation, varying from $3.69 \times 10^{-4}$ to $5.13 \times 10^{-4} \mathrm{~s}^{-1}$ during the daytime (10:00 LT-15:00 LT). According to previous studies (Hou et al., 2016; Li et al., 2011), the deposition velocity $\mathrm{V}_{\mathrm{d}}$ and the daytime mixing height $\mathrm{H}$ in Beijing were assumed as $1.6 \mathrm{~cm} \mathrm{~s}^{-1}$ and $500 \mathrm{~m}$, respectively.

Table 2 summarized the daytime HONO production rate from unknown source at different sites. The calculated average $\mathrm{P}_{\text {unknown was }} 0.59 \mathrm{ppb} \mathrm{h}^{-1}$ (ranging from 0.02 to $1.83 \mathrm{ppb} \mathrm{h}^{-1}$ ) in our study, which was lower than those values in most urban sites, but comparable to the values $\left(0.40\right.$ and $\left.0.50 \mathrm{ppb} \mathrm{h}^{-1}\right)$ in sites of Paris and Germany. Interestingly, a larger $\mathrm{P}_{\text {unknown }}\left(0.80 \mathrm{ppb} \mathrm{h}^{-1}\right)$ was found during Period II than the value $\left(0.73 \mathrm{ppb} \mathrm{h}^{-1}\right)$ calculated during Period I. The diurnal contributions of production and loss pathways to the HONO budget during the whole observation period, Period I, and Period II were illustrated in Fig. 5, Fig. S6(a), and Fig. S6(b), respectively. The $\mathrm{P}_{\text {unknown }}$ values are still about 5-6 times greater than the $\mathrm{P}_{\mathrm{OH}+\mathrm{NO}}$ values, suggesting that $\mathrm{P}_{\text {unknown }}$ is the dominant daytime HONO source during the observation period. As the largest 
489 production process, the unknown source could account for up to $87 \%$ of the HONO 490 production. The proportion could even reach up to $92 \%$ during Period II. 491 492

Table 2 Comparison of the HONO concentrations and the derived $\mathrm{P}_{\text {unknown }}$ at different sites

\begin{tabular}{|c|c|c|c|c|}
\hline Site & Date & $\mathrm{HONO} / \mathrm{ppb}$ & $\mathrm{P}_{\text {unknown }} / \mathrm{ppb} \mathrm{h}^{-1}$ & Reference \\
\hline $\begin{array}{c}\text { Beijing } \\
\text { (suburban, China) }\end{array}$ & 2006.8 & 0.45 & 1.00 & (Yang et al., 2014) \\
\hline $\begin{array}{c}\text { Beijing } \\
\text { (urban, China) }\end{array}$ & $2014.2-3$ & 1.95 & $1.26-1.85$ & (Hou et al., 2016) \\
\hline $\begin{array}{c}\text { Beijing } \\
\text { (urban, China) }\end{array}$ & $\begin{array}{l}2015.9- \\
2016.7\end{array}$ & 5.97 & 3.05 & (Wang et al., 2017) \\
\hline $\begin{array}{c}\text { Beijing } \\
\text { (urban, China) }\end{array}$ & 2016.12 & 3.5 & $0.98-1.25$ & (Zhang et al., 2019b) \\
\hline $\begin{array}{c}\text { Beijing } \\
\text { (urban, China) }\end{array}$ & 2018.8-9 & 1.23 & 2.33 & (Jia et al., 2020) \\
\hline $\begin{array}{c}\text { Beijing } \\
\text { (urban, China) }\end{array}$ & 2019.6-7 & 0.44 & 0.59 & This study \\
\hline $\begin{array}{c}\text { Jinan } \\
\text { (urban, China) }\end{array}$ & $\begin{array}{l}2015.9- \\
2016.8\end{array}$ & 1.15 & 2.95 & (Li et al., 2018a) \\
\hline $\begin{array}{c}\text { Xi'an } \\
\text { (urban, China) }\end{array}$ & $2015.7-8$ & 1.04 & 0.75 & (Huang et al., 2017) \\
\hline $\begin{array}{c}\text { Shanghai } \\
\text { (urban, China) }\end{array}$ & 2016.5 & 2.31 & $1.78-2.98$ & (Cui et al., 2018) \\
\hline $\begin{array}{l}\text { Guangzhou } \\
\text { (rural, China) }\end{array}$ & 2004.10 & 1.25 & 4.90 & (Su et al., 2008b) \\
\hline $\begin{array}{c}\text { Paris } \\
\text { (suburban, France) }\end{array}$ & 2009.7 & 0.10 & 0.40 & (Michoud et al., 2014) \\
\hline $\begin{array}{c}\text { Jülich } \\
\text { (rural, Germany) }\end{array}$ & $2003.7-8$ & 0.14 & 0.50 & (Kleffmann et al., 2005) \\
\hline
\end{tabular}




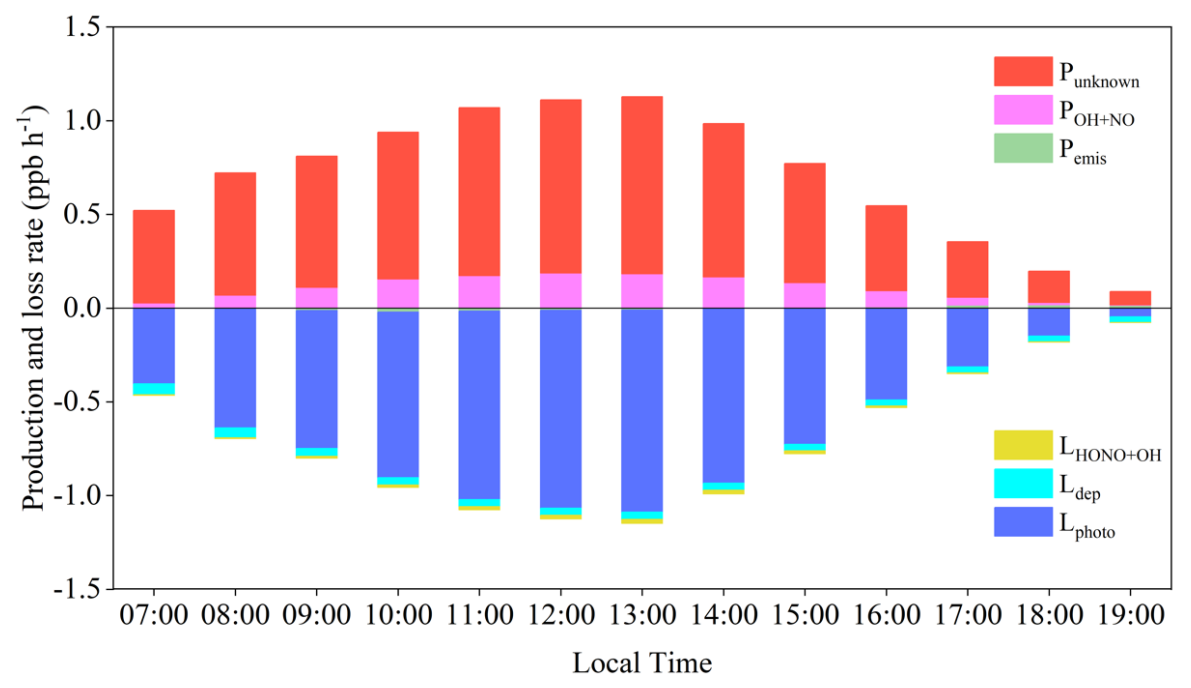

Fig. 5 Diurnal production and loss rates for the daytime HONO budget

496

Understanding the potential unknown daytime sources of HONO is a challenging task. Of note, as shown in Fig. 5, $\mathrm{P}_{\text {unknown }}$ climbed to the maximum at noon (13:00 LT) and then gradually decreased. It could be inferred that the unknown source may be relevant to solar radiation. Correlation analysis of $\mathrm{P}_{\text {unknown }}$ with several parameters related to the processes identified as HONO sources has been widely used to diagnose the unknown source. The correlations of $\mathrm{P}_{\text {unknown }}$ against $J_{\mathrm{NO} 2}$ and $\mathrm{RH}\left(\mathrm{R}^{2}<0.1\right.$, Fig. S7 and S8) did not show any clear relationships. To characterize the effect of aerosol and photo-enhanced $\mathrm{NO}_{2}$ conversion on unknown $\mathrm{HONO}$ sources, the relationships between $\mathrm{P}_{\text {unknown }}$ and (a) $\mathrm{PM}_{2.5}$ concentrations, (b) $\mathrm{PM}_{2.5} \times \mathrm{NO}_{2}$, (c) $J_{\mathrm{NO} 2} \times \mathrm{NO}_{2}$, and (d) $\mathrm{PM}_{2.5} \times J_{\mathrm{NO} 2} \times \mathrm{NO}_{2}$ were analyzed, respectively. As shown in Fig. 6 , the $\mathrm{P}_{\text {unknown }}$ increased gradually with the increase of $\mathrm{PM}_{2.5}$ concentrations, $\mathrm{PM}_{2.5} \times \mathrm{NO}_{2}$ values, $J_{\mathrm{NO} 2} \times \mathrm{NO}_{2}$ values and $\mathrm{PM}_{2.5} \times J_{\mathrm{NO} 2} \times \mathrm{NO}_{2}$ values. Moreover, the positive correlations between $\mathrm{P}_{\text {unknown }}$ and the above parameters signified that the photo-enhanced $\mathrm{NO}_{2}$ conversion on aerosol surface could act as a missing source for daytime HONO. The correlation relationships obtained in this study were not as high as those in previous studies(Cui et al., 2018; Jia et al., 2020; Li et al., 2018b; Wang et al., 2017). Though the researches of Ziemba et al (2010), Rutter et al (2014), Leong et al (2016) and Gall et al (2016), it can be learned that the heterogeneous conversion of $\mathrm{HNO}_{3}$ on primary organic aerosol emitted by motor vehicles and the homogeneous VOCs-mediated conversion of $\mathrm{HNO}_{3}$ 
516 to HONO could also be the main HONO sources. Additionally, the photolysis of total 517 nitrate $\left(\mathrm{HNO}_{3}\right.$ and particle nitrate) have been considered as potential formation 518 pathways of ambient HONO in several other studies (Ye et al., 2016; Zhang et al., 2020; 519 Zhou et al., 2011). However, it was a pity that $\mathrm{HNO}_{3}$ and particulate nitrate were not 520 observed during the sampling period. The effect of total nitrate on HONO formation 521 could not be evaluated in this study. Considering the significant role of total nitrate, the 522 conversion of total nitrate to HONO in ozone pollution period will be studied in the 523 future.
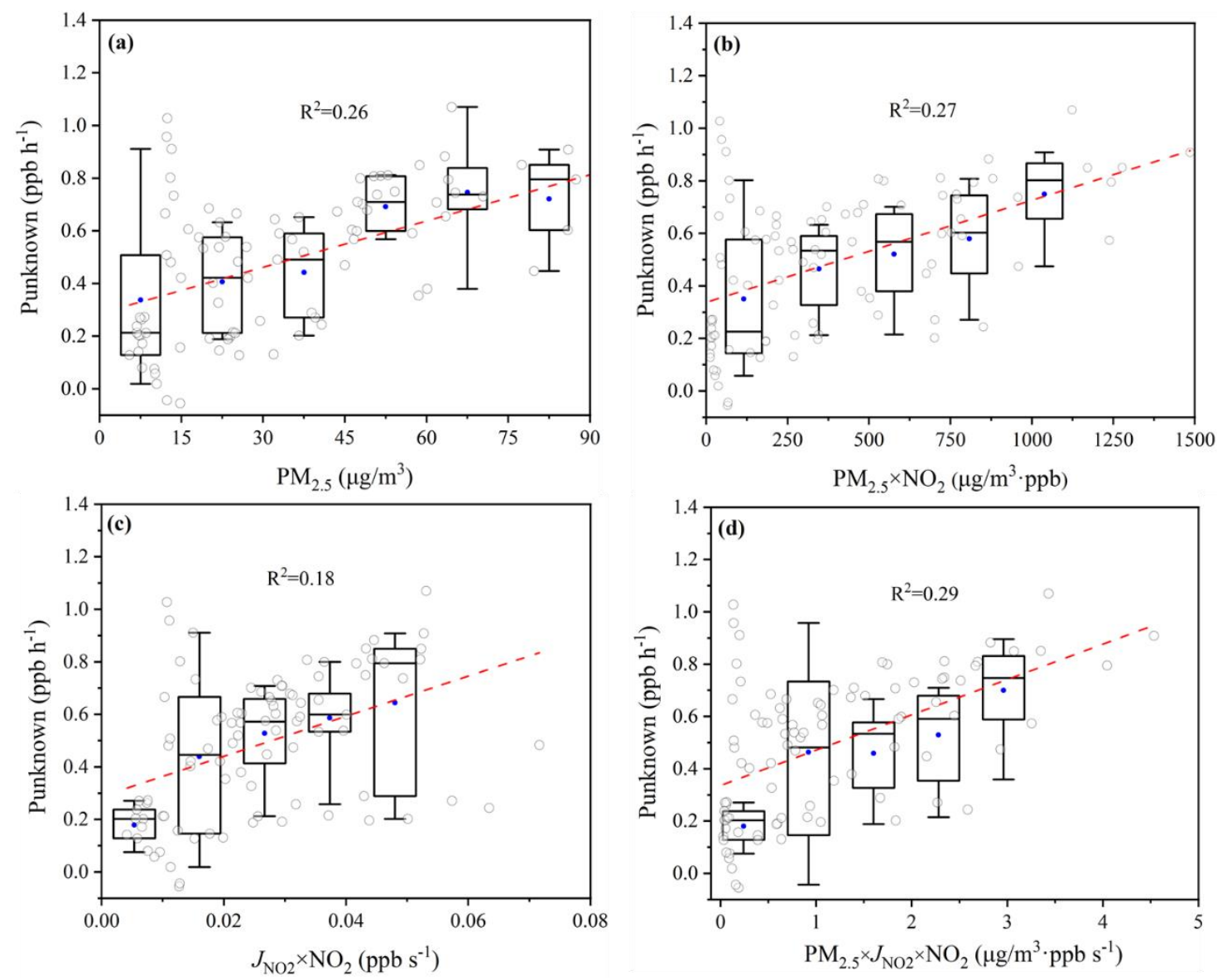

Fig. 6 The correlations between $\mathrm{P}_{\text {unknown }}$ and $\mathrm{PM}_{2.5}$ (a), $\mathrm{PM}_{2.5} \times \mathrm{NO}_{2}(\mathrm{~b}), J_{\mathrm{NO}_{2}} \times \mathrm{NO}_{2}$ (c) and $\mathrm{PM}_{2.5} \times J_{\mathrm{NO} 2} \times \mathrm{NO}_{2}(\mathrm{~d})$. Mean (blue circle), median (middle horizontal line), 25 th 529 and 75th percentiles (P25-P75, box), 10th and 90th percentiles (P10-P90, whiskers).

\subsection{Impact of HONO on $\mathrm{AOC}, \mathrm{OH}$ and $\mathrm{O}_{3}$ budget}

It is known that photolysis of $\mathrm{HONO}$ plays a crucial role for $\mathrm{OH}$ radical production 
532 in the atmosphere. The elevated levels of daytime HONO indicated that a strong 533 atmospheric oxidizing capacity exists in the atmosphere in Beijing. Additionally, $\mathrm{OH}$ 534 radical acts as an important role in ozone photochemistry. Since the ozone pollution 535 was severe during the observation period, the production and loss rates of $\mathrm{O}_{3}$ were also 536 quantified. Fig. 7 showed the simulated average diurnal profiles of AOC, primary 537 production rates of $\mathrm{OH}$ radical, $\mathrm{O}_{3}$ production, and loss budget with and without $\mathrm{HONO}$ 538 data constraints. The meaning of "without HONO data constraints" is that the measured 539 HONO concentrations are not entered into the OBM model. The calculated AOC with 540 and without HONO constrained were up to $8.58 \times 10^{7}$ and $6.63 \times 10^{7}$ molecules $\mathrm{cm}^{-3} \mathrm{~s}^{-}$ $541^{1}$ at noon, with average daytime (7:00-19:00 LT) values of $4.33 \times 10^{7}$ and $3.27 \times 10^{7}$ 542 molecules $\mathrm{cm}^{-3} \mathrm{~s}^{-1}$, respectively. The AOC levels were relatively lower than those 543 determined at the same site in 2008 (Yang et al. 2018), but comparable to the values at 544 a background site in Hong Kong (Li et al., 2018b). This implied the decreased oxidation 545 capacity due to the implementation of strict emission reduction measures taken in 546 Beijing in recent years. $\mathrm{OH}$ was the predominant oxidant, as expected, accounting for $54788 \%$ and $85 \%$ of the AOC with and without HONO constrained, respectively. During 548 the nighttime, the contributions from $\mathrm{O}_{3}$ and $\mathrm{NO}_{3}$ to $\mathrm{AOC}$ began to increase due to low 549 OH levels.

550 Here we calculated the production rate of $\mathrm{OH}$ radicals from $\mathrm{HONO}$ photolysis and 551 compared it with those from other sources, including $\mathrm{O}_{3}$ photolysis, OVOCs photolysis 552 as well as ozonolysis of alkenes (Fig. 7 (c) and (d)). In terms of the daytime average, $553 \mathrm{HONO}$ photolysis was the largest contributor to $\mathrm{OH}$ production with an average value 554 of $0.93 \mathrm{ppb} \mathrm{h}^{-1}$, followed by $\mathrm{O}_{3}$ photolysis $\left(0.36 \mathrm{ppb} \mathrm{h}^{-1}\right)$, and ozonolysis of alkenes $555\left(0.16 \mathrm{ppb} \mathrm{h}^{-1}\right)$. The contribution of OVOCs photolysis could be neglected with an 556 average of $0.03 \mathrm{ppb} \mathrm{h}^{-1}$. Even at noontime, HONO photolysis still presented the 557 dominant contributor of $\mathrm{OH}$ production, which was consistent with the conclusion in 558 the previous study ( $\mathrm{Li}$ et al., 2018a). When HONO concentration was not constrained, 559 the contribution from HONO photolysis was much underestimated reaching up to $89 \%$ $560 \quad\left(0.10 \mathrm{ppb} \mathrm{h}^{-1}\right)$.

561 To accurately evaluate the impacts of $\mathrm{HONO}$ on in-situ photochemical $\mathrm{O}_{3}$ 
562 production, the diurnal variations of $\mathrm{O}_{3}$ production and loss rates with and without 563 HONO were depicted in Fig. 7 (e) and (f). The average $\mathrm{O}_{3}$ production is dominated by 564 the $\mathrm{HO}_{2}+\mathrm{NO}$ and other $\mathrm{RO}_{2}+\mathrm{NO}$ reactions. For the average $\mathrm{O}_{3}$ loss, the predominate 565 two pathways are $\mathrm{NO}_{2}+\mathrm{OH}$ and $\mathrm{NO}_{2}+\mathrm{RO}_{2}$ reactions. Other reactions including 566 VOCs $+\mathrm{O}_{3}, \mathrm{VOCs}+\mathrm{NO}_{3}, \mathrm{NO}_{2}+\mathrm{RO}_{2}$, and Heter.loss $\mathrm{N}_{2} \mathrm{O}_{5}$ dominated the $\mathrm{O}_{3}$ loss during 567 the nighttime. All pathways except $\mathrm{O}_{3}$ photolysis and other reactions were 568 underestimated when $\mathrm{HONO}$ data were not constrained in the model. The net $\mathrm{O}_{3}$ 569 production rate can be obtained as the difference between the production and 570 destruction rate. In this study, the daytime average net production rate was $10.19 \mathrm{ppb} \mathrm{h}^{-1}$ 571 with HONO constrained, which was 1.2 times higher than the value $\left(8.18 \mathrm{ppb} \mathrm{h}^{-1}\right)$ 572 without HONO constrained.

573 Note that the homogeneous reaction of $\mathrm{OH}+\mathrm{NO}$ was the only source of HONO in 574 the model now, the differences of the simulated results between the two cases could 575 suggest the contribution of other additional sources of HONO. The model without 576 observed HONO data constraint would largely underestimate the $\mathrm{AOC}, \mathrm{OH}$ production 577 rate and net ozone production rate. These results verified the significant roles of HONO 578 and additional HONO sources in atmospheric photochemistry. However, the direct 579 HONO observations are limited in photochemical monitoring networks in China and 580 the unknown sources of HONO are still unclear. To accurately simulate atmospheric 581 oxidation processes, further investigation is required to figure out the mechanisms of 582 HONO sources in the future. 

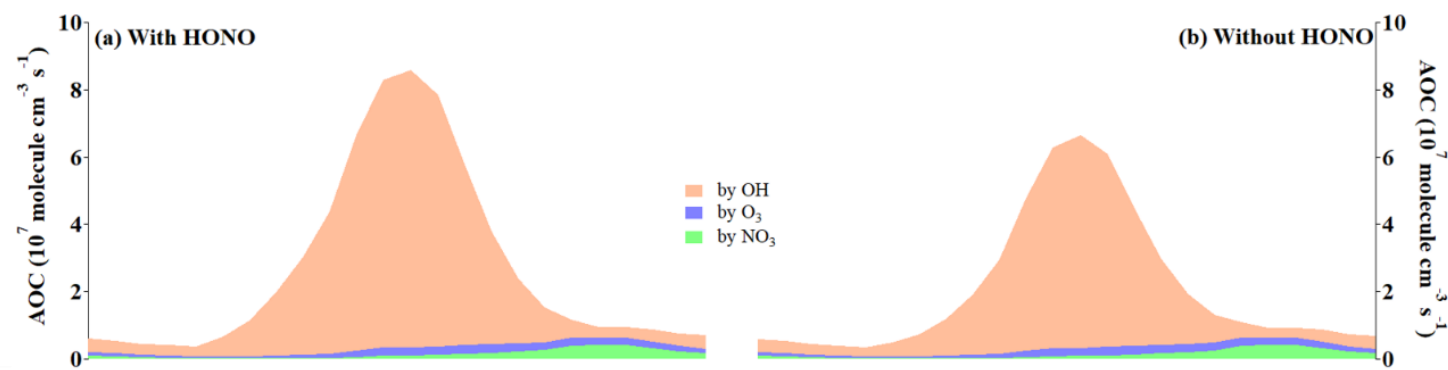

${ }^{3.0} 7$ (c) With HONO
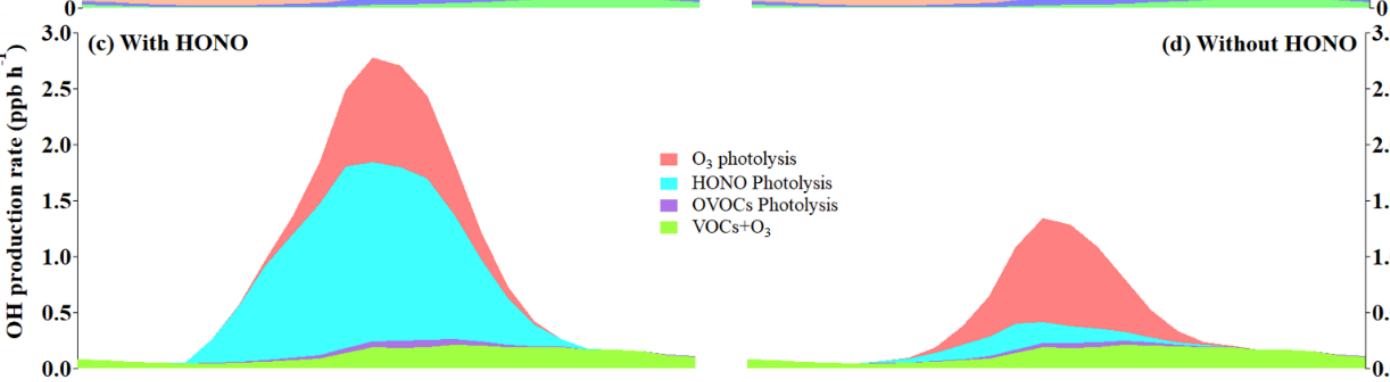

$\left.\simeq \begin{array}{c}0.0 \\ \simeq\end{array}\right](\mathrm{e})$ With HONO

OVOCs Photolysis

VOCs $+\mathrm{O}_{3}$

\section{Conclusions}

High time-resolution field observation of $\mathrm{HONO}$, together with other air pollutants and meteorological parameters were conducted at an urban site in Beijing from June to July 2019. A haze pollution period (Period I) and an ozone pollution period (Period II) constraints during Period II. were selected for a comparative study of two typical cases. Higher HONO concentrations and $\mathrm{HONO} / \mathrm{NO}_{2}$ ratios were found during Period I than those during Period II, implying that the heterogeneous conversion from $\mathrm{NO}_{2}$ on aerosol surfaces may contribute to HONO formation. Direct vehicle emission exhibited significant contribution from $15 \%$ to $40 \%$ on ambient $\mathrm{HONO}$ at night. The calculated homogeneous formation rate and heterogeneous conversion frequency of $\mathrm{NO}_{2}$ to HONO formation during Period I were higher than those during Period II. Compared 
600 with the homogeneous reaction of $\mathrm{NO}$ with $\mathrm{OH}$, the heterogeneous conversion from $601 \mathrm{NO}_{2}$ was the dominant source for nocturnal HONO formation. The calculation results 602 found that the daytime unknown source $\mathrm{P}_{\text {unknown }}\left(0.80 \mathrm{ppb} \mathrm{h}^{-1}\right)$ during Period II was 603 higher than that $\left(0.73 \mathrm{ppb} \mathrm{h}^{-1}\right)$ during Period I. Correlations analysis presented that the 604 photo-enhanced $\mathrm{NO}_{2}$ conversion on the aerosol surface appeared to be a missing $\mathrm{HONO}$ 605 source. The model simulations showed that the oxidant reactions initiated by $\mathrm{OH}$ 606 radicals accounted for $88 \%$ of the atmospheric oxidation capacity (AOC) during an 607 ozone pollution period. HONO photolysis was the dominant source of daytime $\mathrm{OH}$ 608 production, and the average $\mathrm{O}_{3}$ production was dominated by the $\mathrm{HO}_{2}+\mathrm{NO}$ and other $609 \mathrm{RO}_{2}+\mathrm{NO}$ reactions. It could be inferred that the model without the constraint of HONO data would largely underestimate the $\mathrm{AOC}, \mathrm{OH}$ production rates, and $\mathrm{O}_{3}$ production 611 rates in the urban atmosphere. This study provides some insight into the variation, 612 sources and effect of HONO on atmospheric photochemistry in the summertime of 613 Beijing. However, we will further investigate the possible sources of HONO during the 614 ozone episodes and clarify the role of $\mathrm{HONO}$ in ozone formation by using a combination of field observation, experimental simulation and model simulation 617

618 methods.

\section{Author contributions}

Yunfeng Li: Conceptualization, Investigation, Data Curation, Writing-Original Draft, Writing-Review \& Editing, Visualization; Xuezhong Wang: Funding acquisition, Resources, Supervision; Zhenhai Wu: Resources, Data Curation; Ling Li: Data Curation; Chuhan Wang: Data Curation; Hong Li: Conceptualization, Methodology, Writing-Review \& Editing, Funding acquisition; Xin Zhang: Software; Yingnan Zhang: Software, Visualization; Junling Li: Resources; Rui Gao: Conceptualization, Methodology; Funding acquisition; Likun Xue: Methodology, Software, Writing-Review \& Editing; Abdelwahid Mellouki: Methodology, Resources; Yangang Ren: Software, Writing-Review \& Editing; Qingzhu Zhang: Methodology. 


\section{Declaration of competing interest}

The authors declare that they have no known competing financial interests or personal relationships that could have appeared to influence the work reported in this paper.

\section{Acknowledgements}

We are grateful to the National Center Atmospheric Research for providing the TUV model. This work was financially supported by the programs from Beijing Municipal Science \& Technology Commission (No. Z181100005418015) and the Fundamental Research Funds for Central Public Welfare Scientific Research Institutes of China, Chinese Research Academy of Environmental Sciences (No. 2019YSKY-012, 2019YSKY-018), the program from National Nature Science Foundation of China (No. 41907197). The authors acknowledge the support provided by Junfei Guo and Yu Xiang from Beijing Wisdom Technology Company Limited.

\section{Appendix A. Supplementary data}

Supplementary data to this article can be found online at $\operatorname{xxxxxx}$.

\section{References}

Acker, K., et al., 2006a. Nitrous acid in the urban area of Rome. Atmos. Environ. 40, 3123-3133.

Acker, K., et al., 2005. Concentrations of nitrous acid, nitric acid, nitrite and nitrate in the gas and aerosol phase at a site in the emission zone during ESCOMPTE 2001 experiment. Atmos. Res. 74, 507-524.

Acker, K., et al., 2006b. Strong daytime production of $\mathrm{OH}$ from $\mathrm{HNO}_{2}$ at a rural mountain site. Geophys. Res. Lett. 33, L02809.

Bernard, F., et al., 2016. Measurements of nitrous acid (HONO) in urban area of Shanghai, China. Environ. Sci. Pollut. Res. Int. 23, 5818-5829. 
Burling, I.R., et al., 2010. Laboratory measurements of trace gas emissions from biomass burning of fuel types from the southeastern and southwestern United States. Atmos. Chem. Phys. 10, 11115-11130.

Cheng, X., et al., 2018. Atmospheric isoprene and monoterpenes in a typical urban area of Beijing: Pollution characterization, chemical reactivity and source identification. J. Environ. Sci. 71, 150-167.

Cui, L.L., et al., 2018. An observational study of nitrous acid (HONO) in Shanghai, China: The aerosol impact on HONO formation during the haze episodes. Sci. Total Environ. 630, 1057-1070.

Czader, B.H., et al., 2012. Modeling nitrous acid and its impact on ozone and hydroxyl radical during the Texas Air Quality Study 2006. Atmos. Chem. Phys. 12, 69396951.

Elshorbany, Y.F., et al., 2009. Oxidation capacity of the city air of Santiago, Chile. Atmos. Chem. Phys. 9, 2257-2273.

Finlayson-Pitts, B.J., et al., 2003. The heterogeneous hydrolysis of $\mathrm{NO}_{2}$ in laboratory systems and in outdoor and indoor atmospheres: An integrated mechanism. Phys. Chem. Chem. Phys. 5, 223-242.

Fu, X., et al., 2019. The significant contribution of HONO to secondary pollutants during a severe winter pollution event in southern China. Atmos. Chem. Phys. 19, $1-14$.

Gall, E.T., et al., 2016. Evaluation of nitrous acid sources and sinks in urban outflow. Atmos. Environ. 127, 272-282.

Han, C., et al., 2016. Heterogeneous photochemical conversion of $\mathrm{NO}_{2}$ to $\mathrm{HONO}$ on the humic acid surface under simulated sunlight. Environ. Sci. Technol. 50, 50175023.

He, Y., et al., 2006. Importance of dew in controlling the air-surface exchange of HONO in rural forested environments. Geophys. Res. Lett. 33, L02813.

Heland, J., et al., 2001. A new instrument to measure gaseous nitrous acid (HONO) in the atmosphere. Environ. Sci. Technol. 35, 3207-3212.

Hendrick, F., et al., 2014. Four years of ground-based MAX-DOAS observations of 
HONO and $\mathrm{NO}_{2}$ in the Beijing area. Atmos. Chem. Phys. 14, 765-781.

Hofzumahaus, A., et al., 2009. Amplified trace gas removal in the troposphere. Science $324,1702-1704$.

Hou, S., et al., 2016. Comparison of atmospheric nitrous acid during severe haze and clean periods in Beijing, China. Atmos. Environ. 124, 199-206.

Huang, R.J., et al., 2017. Concentration and sources of atmospheric nitrous acid (HONO) at an urban site in Western China. Sci. Total Environ. 593-594, 165-172.

Jenkin, M.E., et al., 2003. Protocol for the development of the Master Chemical Mechanism, MCM v3 (Part B): tropospheric degradation of aromatic volatile organic compounds. Atmos. Chem. Phys. 3, 181-193.

Jia, C.H., et al., 2020. Pollution characteristics and potential sources of nitrous acid (HONO) in early autumn 2018 of Beijing. Sci. Total Environ. 735, 139317.

Jiang, Y., et al., 2020. Sources of nitrous acid (HONO) in the upper boundary layer and lower free troposphere of the North China Plain: insights from the Mount Tai Observatory. Atmos. Chem. Phys. 20, 12115-12131.

Kang, C. M., et al., 2006. Source identification and trends in concentrations of gaseous and fine particulate principal species in Seoul, South Korea. J. Air Waste Manage. $56,911-921$.

Kleffmann, J., et al., 2005. Daytime formation of nitrous acid: A major source of $\mathrm{OH}$ radicals in a forest. Geophys. Res. Lett. 32, 347-354.

Kleffmann, J., et al., 2003. Measured and simulated vertical profiles of nitrous acidPart I: Field measurements. Atmos. Environ. 37, 2949-2955.

Kurtenbach, R., et al., 2001. Investigations of emissions and heterogeneous formation of HONO in a road traffic tunnel. Atmos. Environ. 35, 3385-3394.

Leong, Y.J., et al., 2016. Impact of environmental variables on the reduction of nitric acid by proxies for volatile organic compounds emitted by motor vehicles. Atmos. Pollut. Res. 7, 221-227.

Li, D.D., et al., 2018a. Characteristics and sources of nitrous acid in an urban atmosphere of northern China: Results from 1-yr continuous observations. Atmos. Environ. 182, 296-306. 
Li, X., et al., 2012. Exploring the atmospheric chemistry of nitrous acid (HONO) at a rural site in Southern China. Atmos. Chem. Phys. 12, 1497-1513.

Li, Y., et al., 2011. Impacts of HONO sources on the air quality in Beijing, Tianjin and Hebei Province of China. Atmos. Environ. 45, 4735-4744.

Li, Z.Y., et al., 2018b. Oxidizing capacity of the rural atmosphere in Hong Kong, Southern China. Sci. Total Environ. 612, 1114-1122.

Liu, Y., et al., 2017. Direct emission of nitrous acid (HONO) from gasoline cars in China determined by vehicle chassis dynamometer experiments. Atmos. Environ. 169, 89-96.

Liu, Y., et al., 2019. Semi-quantitative understanding of source contribution to nitrous acid (HONO) based on 1 year of continuous observation at the SORPES station in eastern China. Atmos. Chem. Phys. 19, 13289-13308.

Liu, Y., et al., 2020. The promotion effect of nitrous acid on aerosol formation in wintertime in Beijing: the possible contribution of traffic-related emissions. Atmos. Chem. Phys. 20, 13023-13040.

Liu, Z., et al., 2014. Evidence of aerosols as a media for rapid daytime HONO production over China. Environ. Sci. Technol. 48, 14386-14391.

Lu, K.D., et al., 2014. Nighttime observation and chemistry of HOx in the Pearl River Delta and Beijing in summer 2006. Atmos. Chem. Phys. 14, 4979-4999.

Ma, Q.X., et al., 2017. $\mathrm{SO}_{2}$ initiates the efficient conversion of $\mathrm{NO}_{2}$ to $\mathrm{HONO}$ on $\mathrm{MgO}$ surface. Environ. Sci. Technol. 51, 3767-3775.

Meng, F., et al., 2020. High-resolution vertical distribution and sources of HONO and $\mathrm{NO}_{2}$ in the nocturnal boundary layer in urban Beijing, China. Atmos. Chem. Phys. 20, 5071-5092.

Michoud, V., et al., 2014. Study of the unknown HONO daytime source at a European suburban site during the MEGAPOLI summer and winter field campaigns. Atmos. Chem. Phys. 14, 2805-2822.

Monge, M.E., et al., 2010. Light changes the atmospheric reactivity of soot. Proc. Natl. Acad. Sci. 107, 6605-6609.

Nakashima, Y., Kajii, Y., 2017. Determination of nitrous acid emission factors from a 
gasoline vehicle using a chassis dynamometer combined with incoherent broadband cavity-enhanced absorption spectroscopy. Sci. Total Environ. 575, 287293.

Nakashima, Y., et al., 2017. Contributions of vehicular emissions and secondary formation to nitrous acid concentrations in ambient urban air in Tokyo in the winter. Sci. Total Environ. 592, 178-186.

Nie, W., et al., 2015. Influence of biomass burning plumes on HONO chemistry in eastern China. Atmos. Chem. Phys. 15, 1147-1159.

Qin, M., et al., 2009. An observational study of the $\mathrm{HONO}-\mathrm{NO}_{2}$ coupling at an urban site in Guangzhou City, South China. Atmos. Environ. 43, 5731-5742.

Ren, X., et al., 2003. $\mathrm{OH}$ and $\mathrm{HO}_{2}$ Chemistry in the urban atmosphere of New York City. Atmos. Environ. 37, 3639-3651.

Ren, Y., et al., 2020. Role of the dew water on the ground surface in HONO distribution: a case measurement in Melpitz. Atmos. Chem. Phys. 20, 13069-13089.

Rohrer, F., Berresheim, H., 2006. Strong correlation between levels of tropospheric hydroxyl radicals and solar ultraviolet radiation. Nature. 442, 184-187.

Rutter, A.P., et al., 2014. The reduction of $\mathrm{HNO}_{3}$ by volatile organic compounds emitted by motor vehicles. Atmos. Environ. 87, 200-206.

Saunders, S.M., et al., 2003. Protocol for the development of the Master Chemical Mechanism, MCM v3 (Part A): tropospheric degradation of non-aromatic volatile organic compounds. Atmos. Chem. Phys. 3, 161-180.

Shi, X., et al., 2020. Budget of nitrous acid and its impacts on atmospheric oxidative capacity at an urban site in the central Yangtze River Delta region of China. Atmos. Environ. 238, 117725.

Sorgel, M., et al., 2011. Quantification of the unknown HONO daytime source and its relation to $\mathrm{NO}_{2}$. Atmos. Chem. Phys. 11, 10433-10447.

Spataro, F., Ianniello, A., 2014. Sources of atmospheric nitrous acid: state of the science, current research needs, and future prospects. J. Air Waste Manag. Assoc. 64, 12321250.

Spataro, F., et al., 2013. Occurrence of atmospheric nitrous acid in the urban area of 
Beijing (China). Sci. Total Environ. 447, 210-224.

Spataro, F., et al., 2017. Sources of atmospheric nitrous acid (HONO) in the European High Arctic. Rend. Fis. Acc. Lincei. 28, 25-33.

Stutz, J., et al., 2004. Relative humidity dependence of HONO chemistry in urban areas. J. Geophys. Res. 109, D03307.

Stutz, J., Björn A., and Albrecht N., 2002. Nitrous acid formation in the urban atmosphere: Gradient measurements of $\mathrm{NO}_{2}$ and $\mathrm{HONO}$ over grass in Milan, Italy. J. Geophys. Res., 107, 8192.

Su, H., et al., 2011. Soil nitrite as a source of atmospheric HONO and OH radicals. Science. 333, 1616-1618.

Su, H., et al., 2008a. Observation of nighttime nitrous acid (HONO) formation at a nonurban site during PRIDE-PRD2004 in China. Atmos. Environ. 42, 6219-6232.

$\mathrm{Su}, \mathrm{H}$., et al., 2008b. Nitrous acid (HONO) and its daytime sources at a rural site during the 2004 PRIDE-PRD experiment in China. J. Geophys. Res. 113, D14312.

Tan, Z., et al., 2018. Wintertime photochemistry in Beijing: observations of ROx radical concentrations in the North China Plain during the BEST-ONE campaign. Atmos. Chem. Phys. 18, 12391-12411.

Tong, S., et al., 2015. Comparisons of measured nitrous acid (HONO) concentrations in a pollution period at urban and suburban Beijing, in autumn of 2014. J Sci. China Chem. 58, 1393-1402.

USEPA. 1999. Compendium method TO-11A determination of formaldehyde in ambient air using adsorbent cartridge followed by high performance liquid chromatography (HPLC). Compendium of Methods for the Determination of Toxic Organic Compounds in Ambient Air. Second Edition.

Villena, G., et al., 2011. Nitrous acid (HONO) during polar spring in Barrow, Alaska: A net source of OH radicals? J. Geophys. Res. 116, D00R07.

Wang, J., et al., 2017. Observation of nitrous acid (HONO) in Beijing, China: Seasonal variation, nocturnal formation and daytime budget. Sci. Total Environ. 587-588, 350-359.

Wang, S., et al., 2013. Long-term observation of atmospheric nitrous acid (HONO) and 
its implication to local $\mathrm{NO}_{2}$ levels in Shanghai, China. Atmos. Environ. 77, 718724.

Winer, A.M., Biermann, H.W., 1994. Long pathlength differential optical absorption spectroscopy (DOAS) measurements of gaseous $\mathrm{HONO}, \mathrm{NO}_{2}$ and $\mathrm{HCNO}$ in the California South Coast Air Basin. Res. Chem. Intermed. 20, 423-445.

$\mathrm{Xu}, \mathrm{Z}$., et al., 2015. Nitrous acid (HONO) in a polluted subtropical atmosphere: Seasonal variability, direct vehicle emissions and heterogeneous production at ground surface. Atmos. Environ. 106, 100-109.

$\mathrm{Xu}, \mathrm{Z}$., et al., 2013. Evaluating the uncertainties of thermal catalytic conversion in measuring atmospheric nitrogen dioxide at four differently polluted sites in China. Atmos. Environ. 76, 221-226.

Xue, C., et al., 2020. HONO budget and its role in nitrate formation in the rural North China Plain. Environ. Sci. Technol. 54, 11048-11057.

Xue, L.K., et al., 2016. Oxidative capacity and radical chemistry in the polluted atmosphere of Hong Kong and Pearl River Delta region: analysis of a severe photochemical smog episode. Atmos. Chem. Phys. 16, 9891-9903.

Xue, L.K., et al., 2014. Ground-level ozone in four Chinese cities: precursors, regional transport and heterogeneous processes. Atmos. Chem. Phys. 14, 13175-13188.

Xue, L.K., et al., 2013. Sources and photochemistry of volatile organic compounds in the remote atmosphere of western China: Results from the Mt. Waliguan Observatory. Atmos. Chem. Phys. 13, 8551-8567.

Yang, Q., et al., 2014. Daytime HONO formation in the suburban area of the megacity Beijing, China. Sci. China Chem. 57, 1032-1042.

Yang, W., et al., 2018a. Significant HONO formation by the photolysis of nitrates in the presence of humic acids. Environ. Pollut. 243, 679-686.

Yang, W., et al., 2020. Heterogenous photochemical uptake of $\mathrm{NO}_{2}$ on the soil surface as an important ground-level HONO source. Environ. Pollut. 271, 116289.

Yang, X., et al., 2018b. Observations and explicit modeling of summertime carbonyl formation in Beijing: Identification of key precursor species and their impact on atmospheric oxidation chemistry. J. Geophys. Res. Atmos. 123, 1426-1440. 
Yang, X., et al., 2017. Carbonyl compounds at Mount Tai in the North China Plain: Characteristics, sources, and effects on ozone formation. Atmos. Res. 196, 53-61. Ye, C.X., et al., 2016. Photolysis of nitric acid and nitrate on natural and artificial surfaces. Environ. Sci. Technol. 50, 3530-3536.

Yu, X.N., Zhu, B., Zhang, M.G., 2009a. Seasonal variability of aerosol optical properties over Beijing. Atmos. Environ. 43, 4095-4101.

Yu, Y., et al., 2009b. Observations of high rates of $\mathrm{NO}_{2}-\mathrm{HONO}$ conversion in the nocturnal atmospheric boundary layer in Kathmandu, Nepal. Atmos. Chem. Phys. 9, 6401-6415.

Yun, H., et al., 2017. Nitrous acid in a street canyon environment: Sources and contributions to local oxidation capacity. Atmos. Environ. 167, 223-234.

Zhang, H., et al., 2017. Atmospheric volatile organic compounds in a typical urban area of Beijing: Pollution characterization, health Risk assessment and source apportionment. Atmosphere. 8, 61 .

Zhang, J.W., et al., 2019a. Impacts of potential HONO sources on the concentrations of oxidants and secondary organic aerosols in the Beijing-Tianjin-Hebei region of China. Sci. Total Environ. 647, 836-852.

Zhang, W.Q., et al., 2019b. Variations and sources of nitrous acid (HONO) during a severe pollution episode in Beijing in winter 2016. Sci. Total Environ. 648, 253262.

Zhang, W.Q., et al., 2020. Different HONO sources for three layers at the urban area of Beijing. Environ. Sci. Technol. 54, 12870-12880.

Zhang, X., et al., 2019c. Optimization and preliminary application of the detection method of carbonyl compounds in the ambient air. Res. Environ.Sci. 32, 821-829.

Zheng, H., et al., 2020. Contribution of particulate nitrate photolysis to heterogeneous sulfate formation for winter haze in China. Environ. Sci. Technol Lett.7, 632-638.

Zhou, X., et al., 2011. Nitric acid photolysis on forest canopy surface as a source for tropospheric nitrous acid. Nat. Geosci. 4, 440-443.

Zhou, X.L., et al., 2007. Summertime observations of HONO, $\mathrm{HCHO}$, and $\mathrm{O}_{3}$ at the summit of Whiteface Mountain, New York. J. Geophys. Res. Atmos. 112, D08311. 
1

2

3

5

5

6

7

8

9

10

11

12

13

14

15

16

17

18

19

20

21

22

23

24

25

26

27

28

29

30

31

32

33

34

35

36

37

38

39

40

41

42

43

44

45

46

47

48

49

50

51

52

53

54

55

56

57

58

59

60

61

62

63

64

65

867 Ziemba, L.D., et al., 2010. Heterogeneous conversion of nitric acid to nitrous acid on 868 the surface of primary organic aerosol in an urban atmosphere. Atmos. Environ. $869 \quad 44,4081-4089$.

870 